\title{
Global Vaccine Hesitancy Segmentation: A Cross-European Approach
}

\author{
Almudena Recio-Román *, Manuel Recio-Menéndez (D) and María Victoria Román-González \\ Department of Economy and Business, University of Almería, Carretera de Sacramento s/n, \\ 04120 Almería, Spain; mrecio@ual.es (M.R.-M.); mvroman@ual.es (M.V.R.-G.) \\ * Correspondence: arr306@inlumine.ual.es
}

Citation: Recio-Román, A.;

Recio-Menéndez, M.;

Román-González, M.V. Global Vaccine Hesitancy Segmentation: A Cross-European Approach. Vaccines 2021, 9, 617. https://doi.org/ 10.3390 /vaccines 9060617

Academic Editor: Brian D. Poole

Received: 14 April 2021

Accepted: 2 June 2021

Published: 8 June 2021

Publisher's Note: MDPI stays neutral with regard to jurisdictional claims in published maps and institutional affiliations.

Copyright: (c) 2021 by the authors. Licensee MDPI, Basel, Switzerland. This article is an open access article distributed under the terms and conditions of the Creative Commons Attribution (CC BY) license (https:/ / creativecommons.org/licenses/by/ $4.0 /)$.

\begin{abstract}
Vaccine-preventable diseases are global mainly in a globalized world that is characterized by a continuous movement of people and goods across countries. Vaccine hesitancy, the reluctance or refusal to vaccinate despite the availability of vaccines, is rising worldwide. What if the problem of vaccine hesitancy could be most effectively managed when treated globally rather than on a national or regional basis? What if a global vaccine-hesitant segment exists and the differences among countries are not so significant? Based on the Global Marketing Strategy paradigm, this paper shows that seven different cross-European segments exist based on the beliefs, attitudes, and behaviors collected in 28 European countries. These pan-European segments are differentiable (people in those segments have similar characteristics that are visibly dissimilar from the ones in other segments) and actionable (organizations would be able to propose interventions to the hesitant segments based on their profiles). With segmentation being the starting point of many public health intervention strategies for avoiding vaccine-hesitancy, the results recommend moderating the full-adaptation strategy that follows the "context matters" principle suggested by several political and public health international organizations. Embracing a more standardized strategy will allow the development of better services and strategies that support and enable desirable vaccination behaviors.
\end{abstract}

Keywords: vaccine hesitancy; segmentation; social marketing

\section{Introduction}

Vaccine hesitancy - the reluctance or refusal to vaccinate despite the availability of vaccines- is rising worldwide. Even though vaccines are considered one of the most important achievements of public health, preventing an estimated 2.5 million deaths each year worldwide and reducing disease-specific treatment costs [1], the World Health Organization (WHO) identified vaccine hesitancy as one of the top ten global health threats of 2019 [2].

Vaccine hesitancy is not a new trend. Since 1795, when Edward Jenner published the book titled "An Inquiry into the Cowpox", vaccination has become a mainstream medical practice all over the world [3]. Nevertheless, from their beginnings, inoculations have had their detractors. The earliest ones were men of the church. They reasoned that infectious diseases were a God-given fact of life and death. Some medical doctors, those that were earning a lot of money from useless but lucrative cures, also enrolled in the anti-vaccination movement early [3]. Vaccination was associated with diverse hazards including tuberculosis, cancer, madness, blood poisoning, and syphilis [4]. From the middle of the 19th century, Great Britain and the countries under its influence made vaccination compulsory. Parents that refused to inoculate their children were sent to prison. The results were disastrous, with social riots that ended with the abolishment of the acts that made vaccination compulsory in 1909. The lessons provided by these first experiences were clear: the risks of vaccination must not be silenced, and compulsory vaccination was not the answer to the lack of public confidence in vaccines. 
Nowadays, vaccine doubters are increasing in number. In several Western countries, diseases that had nearly been eradicated are coming into sight again due to their vaccine rates weakening. Vaccine refusal has been increasing in many EU member states [5]. Between 2000 and 2019, the uptake of measles-containing-vaccine first-dose has decreased in $12 \mathrm{EU}$ member states [6]. Moreover, $14 \mathrm{EU}$ member states were below the immunization rate threshold of $95 \%$ that was required to achieve herd immunity in 2019 [7]. The same situation could be found in seasonal influenza and other infectious diseases [5]. The last episode of vaccine hesitancy is related to the COVID-19 pandemic. Some people are afraid that the pace of both scientific review and vaccine control could compromise safety. Differences in acceptance rates rage enormously from country to country around the world [8,9]. Governments, public health officials, pharmacy companies, and other stakeholders are worried about people's willingness to receive vaccines when appropriate [10].

Vaccine-preventable diseases are global in nature. National immunization programs would benefit from coordinated analysis, action, and control to combat cross-border health threats [11]. In order to avoid the negative consequences of the vaccine hesitancy across the general population, it is necessary, first, to determine population sub-groups that adopt that behavior and, second, to reduce any fear or concern and manage the demand for vaccines [12]. Organizations such as governments and public health services face their particular bundle of distinctive challenges. Based on the premise that context matters, the scientific literature has mostly identified a set of key processes that could overcome hesitancy barriers and would enhance vaccine uptake on a nation-by-nation basis [13]. What if the problem of vaccine hesitancy could be most effectively managed when treated globally rather than on a national or regional basis? What if a global vaccine-hesitant segment exists and the differences among countries are not so significant?

Independent of the pro-vaccination strategy to follow, audience targeting and segmentation strategy are the keys to success [13]. People's attitudes, values, and observed behaviors are the basis to obtain insights for better targeting the intervention mix to maximize vaccine uptake [14]. Organizations that work in worldwide markets face the dilemma of whether to segment markets on a country-by-country basis or to treat the different segments that exist with adapted value propositions, or whether to target one or more similar segments in a standardized way with the same intervention mix-also known as cross-market segmentation-[15]. Public health has used health education, health promotion, and social marketing as effective tools for influencing behavior in the fight against several communicable and non-communicable diseases [16]. Identifying global vaccination segments, to the extent that they exist, would allow designing and implementing a more efficient and effective public health intervention strategy, since cross-country segments would be targetable with similar activities.

To the best of our knowledge, the Global Marketing Strategy (GMS) paradigm has not been applied to fight against infectious diseases by supranational political institutions and health organizations. GMS proposes that a global organization must standardize its marketing programs across countries as much as possible, mainly concerning its product offering, promotional mix, price, and channel structure [17]. Most of the guidelines that international and national health organizations and governments suggest following when designing a social marketing vaccination strategy are not global [16,18-22]. Based on the principle of "context matters", they suggest that different countries must design and implement marketing plans adapted to their "unique" characteristics. It means they have adopted the traditional form of international segmentation known as a multidomestic strategy. Several researchers argue that global marketing strategy plays a critical role in determining an organization's performance in the global market [17,23-25]. Hence, these international political institutions and health organizations that do not apply-or recommend not to apply - the GMS paradigm could be achieving suboptimal outcomes on developing better services and strategies that support and enable desirable vaccination behaviors.

The standardized strategy accompanying the GMS approach enhances performance in sectors in which competition is global in scope [17]. These major benefits are mainly 
obtained through economies of scale and scope, consistency in dealing with the target groups, and the ability to exploit good ideas at a global scale. The global pharmaceutical industry produces vaccines. The pharmaceutical industry is comprised of some major multinational companies operating in a highly global competitive market that has experienced significant growth during the past two decades. Pharmaceutical revenues worldwide totaled USD 1.25 trillion in 2019 [26]. Vaccine hesitancy is also fueled by misinformative campaigns promoted by political, religious, and social organizations on a global scale [27]. Misinformation leads to mistrust in public health organizations and encourages antiscience sentiments [28]. This fake information is transmitted worldwide at lightning speed in a single click. Responding to the global threat posed by vaccine hesitancy with local intervention actions seems not to be enough.

This study is designed to answer two research questions. The first is to confirm whether there are homogeneous segments based on vaccination attitudes, beliefs, and behaviors across European countries. Cross-national segmentation is challenging when cultural and economic differences influence customer preferences [29]. Our study, which analyzes cross-national market segments of individuals with respect to the acceptance of vaccination in 28 European member countries, provides valuable insights into international political and health organizations, companies, practitioners, and academics. The second question is whether the pan-European segments that exhibit higher hesitancy are differentiable (the people in those segments should have similar needs that are visibly dissimilar to the needs of the people in other segments) and actionable (organizations have to be able to propose interventions to the hesitant segments).

\section{Materials and Methods}

The data comes from the EUROBAROMETER survey 91.2 that was carried out between the 15th and the 29th of March 2019, at the request of the European Commission [30]. The dataset was accessed through GESIS (Leibniz-Institute für Sozialwissenschaften, University of Cologne, Germany). The EUROBAROMETER is part of wave 91.2 and covers the population of the respective nationalities of the European Union member states, residents in each of the member states, and aged 15 years and over. In these countries, the survey covers the national population of citizens of the respective nationalities and the population of citizens of all the European Union member states that are resident in those countries and have a sufficient command of one of the respective national language(s) to answer the questionnaire. The basic sample design applied in all states is a multi-stage random one.

The following table (Table 1) shows the sample size in each country and the total population aged 15 or more years.

Table 1. Sample size by country, Total population $15+$.

\begin{tabular}{ccc}
\hline COUNTRY & Number of Interviews & Population 15+ \\
\hline Austria & 1006 & $7,554,711$ \\
Belgium & 1041 & $9,693,779$ \\
Bulgaria & 1026 & $6,537,535$ \\
Croatia & 1010 & $3,796,476$ \\
Czech Republic & 1068 & $9,238,431$ \\
Denmark & 1017 & $4,838,729$ \\
Estonia & 1005 & $1,160,064$ \\
Finland & 1000 & $4,747,810$ \\
\hline
\end{tabular}


Table 1. Cont.

\begin{tabular}{ccc}
\hline COUNTRY & Number of Interviews & Population 15+ \\
\hline France & 1013 & $54,097,255$ \\
Germany & 1507 & $70,160,634$ \\
Greece & 1014 & $9,937,810$ \\
Hungary & 1030 & $8,781,161$ \\
Ireland & 1078 & $3,592,162$ \\
Italy & 1021 & $52,334,536$ \\
Latvia & 1012 & $1,707,082$ \\
Lithuania & 1004 & $2,513,384$ \\
Luxemburg & 512 & 457,127 \\
Malta & 497 & 364,171 \\
Netherlands & 1017 & $13,979,215$ \\
Poland & 1011 & $33,444,171$ \\
Portugal & 1013 & $8,480,126$ \\
Republic of Cyprus & 505 & 741,308 \\
Romania & 1025 & $16,852,701$ \\
Slovakia & 1020 & $4,586,024$ \\
Slovenia & 1016 & $1,760,032$ \\
Spain & 1014 & $39,445,245$ \\
Sweden & 1021 & $7,998,763$ \\
United Kingdom & 1021 & $52,651,777$ \\
\hline TOTAL & 27,524 & $431,452,219$
\end{tabular}

Source: Eurobarometer 91.2. European Commission [30,31] Table A1 (Appendix A) shows the variables selected from this Eurobarometer to perform the analysis and the sample statistical descriptives.

For answering whether cross-European vaccination segments exist based on vaccination attitudes, beliefs and behaviors, we applied a factor-cluster segmentation approach. We selected all the variables shown in Table A1. From the 46 variables, 44 were coded as binary, and 2 as polytomous (the one that asked if "vaccines are effective" and the one that asked "the most trusted info source"). For performing the correct association matrix for the factor analysis-using tetrachoric or polychoric correlations, when appropriate-we used the "polycor" package from R [32]. Aiming to reduce the complexity of the observed data to a more limited set of components and to avoid multicollinearity problems, we computed a principal component analysis (PCA) using the "psych" package from R. Zero frequency cells were replaced by 0.5 considering Yate's correction for continuity [33]. Using the scores for the resulting components, we clustered them choosing the best clustering method between hierarchical methods, K-Means, and PAM considering three internal measures of clustering validation: Connectivity, Dunn, and Silhouette. Attending to the compactness, separation, connectivity, and interpretability of the solution, we chose the optimal number of segments, described and labeled them. For testing whether the pan-European segments that exhibit higher hesitancy were differentiable, we calculated segments' means differences applying an ANOVA (Tukey HSD). To check if the found segments were cross-European, we ran a Bayesian multilevel multinomial analysis. Once we confirmed that there were no differences between countries for the clustering solution, we performed a multinomial logit regression for testing the actionability of the segments. For better interpreting these results, we used marginal effects.

\section{Results}

PCA analysis results are shown in Table A2 (Appendix B). To determine the number of components we ran a parallel analysis [34] using the "psych" package from R. The results of the parallel analysis suggested that 14 components explaining $66 \%$ of the total variance might be most appropriate- $\mathrm{RMSR}=0.05$ and fit based upon off-diagonal values $=0.94-0.0$.

For interpreting the components, we used the Varimax rotated component analysis matrix depicted in Table A2 (Appendix B). Our cutoff point for interpretation purposes was 
all loadings \pm 0.4 or above [35-37]. Considering the loadings, we named the components as depicted in Table 2.

Table 2. Principal Components Analysis (Varimax Rotation).

\begin{tabular}{|c|c|c|c|}
\hline Component \# 1 & $\begin{array}{l}\text { Component } \\
\text { Name }^{1}\end{array}$ & Original Variables with Significant Loadings & $\begin{array}{l}\text { Percentage of } \\
\text { Total Variance }\end{array}$ \\
\hline $\mathrm{C} 1$ & Vaccines not important & $\begin{array}{c}\text { Vaccines important } \\
\text { Vaccines are rigorously tested before being } \\
\text { authorized for use } \\
\text { Everybody needs to have routine vaccinations } \\
\text { Not getting vaccinated can lead to serious } \\
\text { health issues } \\
\text { Vaccines are important to protect not only yourself } \\
\text { but also others } \\
\text { Vaccination of other people is important to protect } \\
\text { those that cannot be vaccinated }\end{array}$ & $9 \%$ \\
\hline $\mathrm{C} 2$ & Infectious diseases kill & $\begin{array}{l}\text { Flu is causing deaths in the EU nowadays } \\
\text { Measles is causing deaths in the EU nowadays } \\
\text { Polio is causing deaths in the EU nowadays } \\
\text { Hepatitis is causing deaths in the EU nowadays } \\
\text { Meningitis is causing deaths in the EU nowadays } \\
\text { Tetanus is causing deaths in the EU nowadays }\end{array}$ & $8 \%$ \\
\hline $\mathrm{C} 3$ & Vaccines are dangerous & $\begin{array}{c}\text { Vaccines overload and weaken the immune system } \\
\text { Vaccines can cause the disease against which } \\
\text { they protect } \\
\text { Vaccines can often produce serious side-effects } \\
\text { Do not know at which level vaccination programs } \\
\text { should be coordinated }\end{array}$ & $5 \%$ \\
\hline $\mathrm{C} 4$ & Vaccine informed & $\begin{array}{l}\text { Seen vaccine info in the last six months on TV } \\
\text { Seen vaccine info in the last six months on the radio } \\
\text { Seen vaccine info in the last six months in } \\
\text { newspapers or magazines } \\
\text { Seen vaccine info in the last six months on online } \\
\text { social networks } \\
\text { Seen vaccine info in the last six months on other } \\
\text { Internet sites }\end{array}$ & $6 \%$ \\
\hline C5 & Children vaccinated & $\begin{array}{l}\text { Have a vaccination card for children } \\
\text { Children vaccinated in the last five years }\end{array}$ & $5 \%$ \\
\hline C6 & Family \& friends info & $\begin{array}{l}\text { If you were looking for information about } \\
\text { vaccination, you would consult family } \\
\text { If you were looking for information about } \\
\text { vaccination, you would consult friends }\end{array}$ & $3 \%$ \\
\hline C7 & $\begin{array}{l}\text { European vaccination } \\
\text { programs }\end{array}$ & $\begin{array}{c}\text { Vaccination programs should be coordinated at } \\
\text { European level } \\
\text { Vaccination programs should be coordinated at a } \\
\text { national level } \\
\begin{array}{c}\text { Vaccination programs should be coordinated at a } \\
\text { regional or local level }\end{array}\end{array}$ & $4 \%$ \\
\hline
\end{tabular}


Table 2. Cont.

\begin{tabular}{|c|c|c|c|}
\hline Component \# 1 & $\begin{array}{l}\text { Component } \\
\text { Name }^{1}\end{array}$ & Original Variables with Significant Loadings & $\begin{array}{l}\text { Percentage of } \\
\text { Total Variance }\end{array}$ \\
\hline $\mathrm{C} 8$ & Information insecurity & $\begin{array}{c}\text { If you were looking for information about } \\
\text { vaccination NONE of the following sources you } \\
\text { would consult } \\
\text { If you were looking for information about } \\
\text { vaccination DO NOT KNOW which of the following } \\
\text { sources you would consult } \\
\text { Family is the source you trust the most for } \\
\text { information on vaccination }\end{array}$ & $4 \%$ \\
\hline C9 & Other sources of info & $\begin{array}{l}\text { If you were looking for information about } \\
\text { vaccination, you would consult other sources } \\
\text { of information } \\
\text { In the past six months, you have seen, read or heard } \\
\text { any information on vaccination in other media }\end{array}$ & $3 \%$ \\
\hline $\mathrm{C} 10$ & Health system info & $\begin{array}{c}\text { If you were looking for information about } \\
\text { vaccination, you would consult other health care } \\
\text { workers (nurses, specialist doctors, etc.) } \\
\text { If you were looking for information about } \\
\text { vaccination, you would consult pharmacists } \\
\text { If you were looking for information about } \\
\text { vaccination, you would consult the } \\
\text { health authorities }\end{array}$ & $3 \%$ \\
\hline
\end{tabular}

I got vaccinated in the last five years

I have a vaccination card

C11 Self-vaccinated

Tend to agree that not getting vaccinated can lead to

serious health issues

Do not know if you or someone in your family had any vaccinations in the last five years

Do not know if you have a vaccination card

C12 Vaccination lack of knowledge

Do not know if you were looking for information

about vaccination, which of the following sources would you consult

Do not know if in the past six months you have seen, read or heard any information on vaccination in the media

If you were looking for information about vaccination you would consult online social networks

If you were looking for information about

C13 Online media info vaccination you would consult other Internet sites In the past six months you have seen, read or heard information on vaccination on online social networks

In the past six months you have seen, read or heard information on vaccination on another Internet sites

C14 International vaccination programs
You think vaccination programs should be coordinated at an international level You have a vaccination card

${ }^{1}$ The fourteen components obtained were labeled in two different ways. First, with a capital C followed by a number (Component \#). This is the name given by R software when using the "psych" library for performing PCA analysis. We maintained these original names without any change for research reproducibility reasons. The other name of each the components were given in the need for obtaining a substantive interpretation of the pattern of the component loadings for the variables. Variables with higher significant factor loadings influenced the name selected to represent a factor to a greater extent [38]. 
In sum, we obtained 14 components out of the 44 original variables that explained $66 \%$ of the total variance. The two most important ones, in terms of the total variance explained individually, were related to the belief that infectious diseases kill $(\mathrm{C} 2,8 \%$ of the total variance) and vaccines are important to fight them ( $\mathrm{C} 1,9 \%$ of the total variance). On the other hand, if we consider all the components that were connected with the information (C4, $\mathrm{C} 6, \mathrm{C} 8, \mathrm{C} 9, \mathrm{C} 10$, and C13) summed up the highest proportion of the total variance explained $(23 \%)$. The rest of the components could also be gathered into three different groups: the first connected with the vaccination status (C5 and C11,9\% of the total variance); the second related to the knowledge about vaccines (C3) and vaccination (C12), which together explained $9 \%$ of the total variance; and, finally, two components (C7 and C14) linked with the international level at which the vaccination programs should be managed ( $7 \%$ of the total variance explained).

Using the factor scores for each of the fourteen components obtained in the previous step for all the interviewees, we proceeded to analyze the different behavioral segments that existed towards vaccination in the European Union. For choosing the best clustering method we used the package "clValid" from R [39]. Hierarchical methods performed better than K-Means and PAM for the three internal measures of clustering validation used (Connectivity, Dunn, and Silhouette). Considering the compactness, separation, connectivity, and interpretability, the seven-cluster solution performed the best. Figure 1 depicts the results of the hierarchical clustering approach (using the squared Euclidean distance and the Ward method). The characteristics of each of the found segments were:

1. Pro-Vaccinators (55.7\% of the sample). It was the most numerous European segment. Following the segment profile represented in Figure 1, people for whom vaccines were the most important for avoiding the negative effects of infectious diseases formed it (in Table A3, Appendix C, we saw that mean differences with all the other segments were statistically significant). It belonged to the group of segments that answered that they felt better informed about vaccines, but the information received was highly insecure. Attending to how the "Information insecurity" component was composed, we saw that it had three significant loadings-the answers "None (SPONTANEOUS)" and "DK" to the question "If you were looking for information about vaccination, which of the following sources would you consult?", and the high importance of the option "Family" when responding the question "And which of the following sources do you trust the most for information on vaccination?"-It portrays a component with the family as the most important source of information about vaccination, under the feeling of insecurity about any information source related to this issue. All the fake news that is present in the information environment is affecting the perception of knowledge, even in the pro-vaccinators segment. Insecurity about information affects the perception of knowledge. Therefore, the Europeans that belonged to this segment had the lowest scores on knowledge about vaccines and vaccination. They were vaccinated in the last five years. Their most preferred source of information was the Health System Info. They agreed that either European or international organizations should manage vaccination programs globally.

2. Self-hesitants $(14.2 \%$ of the sample). It was the second segment that made a point on jabs to avoid infectious diseases. They shared a profile with Pro-vaccinators in relation to the information: they had information but not knowledge about vaccines, and were not personally vaccinated due to information insecurity. They had no doubts about their child's vaccination (see in Figure 1 that they had the highest score of all segments) but they did when they were inoculated. That was why they were labeled as "Self-hesitants". Their favored source of information was Online Media Info, followed by the Health-System Info. They agreed that vaccination programs should be managed by international organizations, with the European authorities being the most preferred ones.

3. Social-hesitants $(9.6 \%$ of the total sample). This segment displayed a medium-range position on the importance of vaccines in avoiding infectious diseases. The respon- 
dents replied having been inoculated in the past five years at the same level as the Pro-vaccinators but their hesitance affected their child's vaccination. They declared themselves to be informed but with a feeling of lack of knowledge about vaccines and vaccination. This led them to information insecurity. They did not trust Online Media Info nor Health System Info preferring, by far, their relatives as the main information source. That is why we called them Social-hesitants. They slightly preferred that international organizations managed the vaccination programs instead of the European authorities.

4. Anti-vaccinators ( $11.7 \%$ of the sample). They showed the lowest confidence in vaccines of all the segments. They declared themselves to be well informed and with top knowledge on vaccines but not on vaccination. They did not feel insecure about the information received. Their unconfident belief caused them not to be open about taking vaccines, but they did not show the same behavior for their children. Their preferred sources of information were Online Media Info and Health System Info. A remarkable characteristic of this segment was that they did not trust international organizations for managing the vaccination programs, mainly favoring the European ones.

5. Alternative-hesitants (2.5\% of the sample). The hesitancy for this group was mainly based on the lack of confidence in Online Media Info and Health System Info. Otherwise, they felt comfortable with Family and Friends Info and showed an absolute preference for Other Sources of Info. In consequence, the reported information insecurity was also high. They portrayed a lack of knowledge about vaccines and vaccination. They shared with the other hesitant groups the lack of confidence in vaccines but, surprisingly, they and their children were among the top segments that had taken vaccines in the last five years.

6. Illiterate-hesitants ( $4 \%$ of the sample). This group share with other hesitants their lack of confidence in vaccines. Their most noteworthy characteristic is that they declared themselves not to be well informed about vaccines. Their vaccination status in the past five years was in the medium range of all groups. The most liked source of information was the Health System Info, closely followed by Online Media Info and Family and Friends. They showed a complete lack of confidence in international organizations when managing the vaccines' programs. European authorities were also not well considered.

7. Uninformed Anti-Vaccinators (2.3\% of the sample). The first distinctive attribute is that they had the lowest score in vaccine trust. Accordingly, they showed the lowest score in believing that infectious diseases kill. They declared themselves to be vaccine informed and to have an average knowledge on vaccines. Nonetheless, they had an absolute lack of knowledge about vaccination. The insecurity felt by this group about the information received was also the highest of all the segments found. It was so high that they did not trust any source of information. They rather preferred that the international organization would manage the vaccination programs. All these sentiments produced low vaccination rates among their children.

For answering the question of whether countries affected the results obtained we ran a Bayesian multilevel multinomial analysis using STAN [40]. The dependent variable was the one with the resulting segments (reference category: Pro-Vaccinators) and as independent variables, we considered each of the fourteen principal components obtained. In doing so, we checked to what extent did the log-odds varied between countries computing an unconditional mean model and calculating the intraclass correlation coefficient (ICC). The parameters used for running the Hamiltonian Monte Carlo sampler algorithm (MCMC) were 2500 warmup iterations, 4 chains, 10,000 iterations per chain, and initials values taken at random. The solution converged $($ Rhat $=1.0)$ and the results are shown in Table 3. 


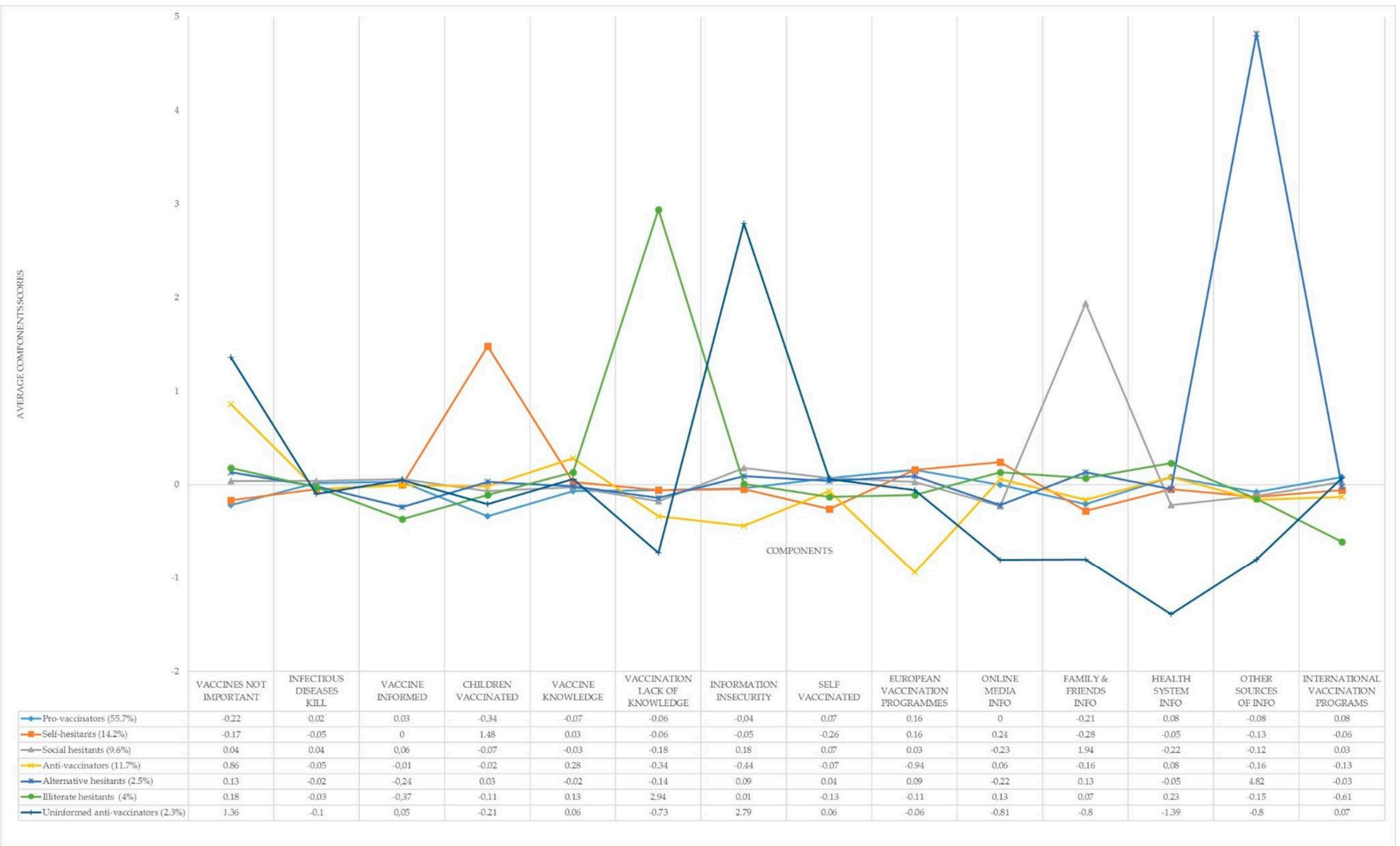

Figure 1. European sentiments towards vaccines. Behavioral segments profile. 
Table 3. Bayesian Multilevel Multinomial Analysis. Unconditional Mean Model (log-odds).

\begin{tabular}{|c|c|c|c|}
\hline & Posterior Mean $^{1}$ & Posterior SD ${ }^{2}$ & Rhat $^{3}$ \\
\hline \multicolumn{4}{|l|}{$\begin{array}{l}\text { Population-level effects (reference } \\
\text { category: Pro-vaccinators) }\end{array}$} \\
\hline Intercept Self-hesitants & -1.38 & 0.07 & 1.0 \\
\hline Intercept Social-hesitants & -1.85 & 0.11 & 1.0 \\
\hline Intercept Anti-vaccinators & -1.63 & 0.12 & 1.0 \\
\hline Intercept Alternative-hesitants & -3.20 & 0.11 & 1.0 \\
\hline Intercept Illiterate-hesitants & -2.90 & 0.17 & 1.0 \\
\hline $\begin{array}{l}\text { Intercept Uninformed } \\
\text { Anti-vaccinators }\end{array}$ & -3.54 & 0.21 & 1.0 \\
\hline \multicolumn{4}{|l|}{$\begin{array}{c}\text { Country-level effects (reference category: } \\
\text { Pro-vaccinators) }\end{array}$} \\
\hline Intercept Self-hesitants & 0.33 & 0.05 & 1.0 \\
\hline Intercept Social-hesitants & 0.58 & 0.09 & 1.0 \\
\hline Intercept Anti-vaccinators & 0.63 & 0.09 & 1.0 \\
\hline Intercept Alternative-hesitants & 0.55 & 0.09 & 1.0 \\
\hline Intercept Illiterate-hesitants & 0.89 & 0.14 & 1.0 \\
\hline $\begin{array}{l}\text { Intercept Uninformed } \\
\text { Anti-vaccinators }\end{array}$ & 1.07 & 0.17 & 1.0 \\
\hline
\end{tabular}

The ICC quantifies the degree of homogeneity of the outcome within countries. The ICC represents the proportion of the between-countries variation $\operatorname{var}\left(u_{0 j}\right)$ in the total variation (Equation (1)).

$$
I C C=\frac{\operatorname{var}\left(u_{0 j}\right)}{\operatorname{var}\left(u_{o j}\right)+\left(\pi^{2} / 3\right)}
$$

In which, $\operatorname{var}\left(u_{0 j}\right)$ is the level-2 variance component and $\left(\pi^{2} / 3\right)$ refers to the standard logistic distribution, that is, the level-1 variance component. The ICC may range from 0 to 1 . ICC $=0$ indicates perfect independence of residuals: The chance to pertain to a behavioral segment does not depend on country membership. However, ICC $=1$ indicates perfect interdependence of residuals: The segment's membership only varies between countries. Calculating, we obtained ICC $=0.095$. In other words, it means that between countries the differences in the segmentation achieved are negligible. Due to this reason, we performed a multinomial logit model for calculating the relationship between the segments and the principal components found (see Table 4).

From Table 4, we noticed that most of the independent variables-the principal components-are statistically significant in explaining the European segments. To improve the interpretability of the regression coefficients, we used marginal effects. The marginal effect is a measure of the instantaneous effect that a change in a particular explanatory variable has on the predicted probability of the dependent variable when the other covariates are kept fixed [41]. The dependent variable is modeled as follows:

$$
y=E(y / x)+\varepsilon,
$$

where $E(y / x)$ is the conditional mean function, $x$ is the vector of explanatory variables and $\varepsilon$ is the error term. The conditional mean function is given by:

$$
E(y / x)=F\left(\beta^{\prime} x\right),
$$

where $\boldsymbol{F}$ denotes a cumulative distribution function and $\beta$ denotes the parameters. Therefore,

$$
\operatorname{Pr}(y=1)=F\left(\beta^{\prime} x\right) .
$$


Marginal effects are obtained by computing the derivative of the conditional mean function given by:

$$
\frac{\partial E(y / x)}{\partial x}=\left[\frac{\partial F\left(\beta^{\prime} x\right)}{\partial \beta^{\prime} x}\right] \beta=f\left(\beta^{\prime} x\right) \beta,
$$

where $f($.$) is the density function that corresponds to the cumulative function F($.$) . The$ marginal effects are nonlinear functions of the parameter estimates and levels of the explanatory variables. Hence, they generally cannot be inferred directly from parameter estimates. In this case, we used the R library called "margins". The results are available in Appendix D, Figures A1-A14.

Table 4. Cross-European Segments Towards Vaccination. Multinomial Logit Model (log-odds).

\begin{tabular}{|c|c|c|c|c|c|c|}
\hline & \multicolumn{6}{|c|}{ Dependent Variable (Reference Category Pro-Vaccinators): } \\
\hline & Self-Hesitants & $\begin{array}{c}\text { Social } \\
\text { Hesitants }\end{array}$ & $\begin{array}{c}\text { Anti- } \\
\text { Vaccinators }\end{array}$ & $\begin{array}{l}\text { Alternative } \\
\text { Hesitants }\end{array}$ & $\begin{array}{l}\text { Illiterate } \\
\text { Hesitants }\end{array}$ & $\begin{array}{c}\text { Uninformed } \\
\text { Anti- } \\
\text { vaccinators }\end{array}$ \\
\hline \multirow{2}{*}{$\mathrm{C} 1$} & -0.088 & $0.593^{* * *}$ & $2.475^{* * *}$ & $2.037 * * *$ & $1.899^{* * *}$ & $3.135 * * *$ \\
\hline & -0.058 & -0.07 & -0.055 & -0.419 & -0.215 & -0.396 \\
\hline \multirow[b]{2}{*}{$\mathrm{C} 2$} & $-0.498 * * *$ & 0.05 & $-0.488^{* * *}$ & -0.076 & $0.619^{* * *}$ & 0.454 \\
\hline & -0.041 & -0.053 & -0.044 & -0.486 & -0.231 & -0.438 \\
\hline \multirow{2}{*}{$\mathrm{C} 3$} & $0.308^{* * *}$ & $0.194^{* * *}$ & $1.141^{* * *}$ & $1.257 * * *$ & $1.591^{* * *}$ & $0.875^{* * *}$ \\
\hline & -0.049 & -0.062 & -0.046 & -0.393 & -0.194 & -0.309 \\
\hline \multirow{2}{*}{$\mathrm{C} 4$} & $-0.262 * * *$ & $-0.249^{* * *}$ & $-0.611^{* * *}$ & -0.691 & $-2.597^{* * *}$ & $-1.617^{* * *}$ \\
\hline & -0.039 & -0.056 & -0.05 & -0.555 & -0.273 & -0.554 \\
\hline \multirow{2}{*}{ C5 } & $2.845^{* * *}$ & $0.157^{* * *}$ & $0.538^{* * *}$ & -0.644 & 0.198 & 0.171 \\
\hline & -0.043 & -0.051 & -0.043 & -0.663 & -0.23 & -0.464 \\
\hline \multirow{2}{*}{ C6 } & $-0.569 * * *$ & $3.694^{* * *}$ & $-0.146^{*}$ & 0.912 ** & $0.673^{* * *}$ & $-3.979 * * *$ \\
\hline & -0.067 & -0.065 & -0.077 & -0.428 & -0.223 & -1.352 \\
\hline \multirow{2}{*}{$\mathrm{C} 7$} & $-0.180^{* * *}$ & $-0.800 * * *$ & $-3.637^{* * *}$ & $-1.922^{* * *}$ & $-1.843^{* * *}$ & $-1.129 * *$ \\
\hline & -0.045 & -0.062 & -0.063 & -0.498 & -0.222 & -0.441 \\
\hline \multirow{2}{*}{$\mathrm{C} 8$} & 0.06 & $-0.720 * * *$ & $0.151^{* *}$ & 0.925 & 0.221 & $3.880 * * *$ \\
\hline & -0.057 & -0.076 & -0.068 & -0.59 & -0.321 & -0.435 \\
\hline \multirow{2}{*}{$\mathrm{C} 9$} & $-0.337^{* * *}$ & $0.537^{* * *}$ & $0.465^{* * *}$ & $5.333 * * *$ & 0.301 & -0.702 \\
\hline & -0.106 & -0.138 & -0.123 & -0.446 & -0.515 & -0.792 \\
\hline \multirow{2}{*}{ C10 } & $-0.264^{* * *}$ & $-0.165^{* *}$ & $-0.729 * * *$ & -1.181 * & -0.014 & $-3.343^{* * *}$ \\
\hline & -0.043 & -0.068 & -0.05 & -0.608 & -0.301 & -0.761 \\
\hline \multirow{2}{*}{$\mathrm{C} 11$} & $-0.378^{* * *}$ & $-0.101^{* *}$ & $-0.359 * * *$ & -0.224 & $-0.851^{* * *}$ & $-1.261^{* *}$ \\
\hline & -0.033 & -0.045 & -0.039 & -0.472 & -0.225 & -0.514 \\
\hline \multirow{2}{*}{$\mathrm{C} 12$} & $0.214^{* *}$ & 0.033 & $0.607^{* * *}$ & $4.421^{* * *}$ & $6.999^{* * *}$ & 0.699 \\
\hline & -0.107 & -0.141 & -0.111 & -0.382 & -0.346 & -0.48 \\
\hline \multirow{2}{*}{ C13 } & $0.546^{* * *}$ & $-0.456^{* * *}$ & $-0.425^{* * *}$ & -0.773 & $-0.704^{* * *}$ & $-3.534^{* * *}$ \\
\hline & -0.037 & -0.056 & -0.048 & -0.487 & -0.248 & -1.045 \\
\hline \multirow{2}{*}{ C14 } & $-0.366^{* * *}$ & $-0.468^{* * *}$ & $-1.092^{* * *}$ & $-1.366^{* * *}$ & $-2.323^{* * *}$ & $-1.013^{* *}$ \\
\hline & -0.036 & -0.048 & -0.041 & -0.373 & -0.202 & -0.409 \\
\hline \multirow{2}{*}{ Constant } & $-3.303^{* * *}$ & $-3.934^{* * *}$ & $-3.039 * * *$ & $-9.268^{* * *}$ & $-8.875^{* * *}$ & $-12.241^{* * *}$ \\
\hline & -0.065 & -0.083 & -0.06 & -0.687 & -0.541 & -1.153 \\
\hline
\end{tabular}

Note: ${ }^{*} p<0.05,{ }^{* *} p<0.01,{ }^{* * *} p<0.001$.

By simultaneously interpreting the data contained in Table 4 and Figures A1-A14, we obtained the following results. Pro-Vaccinators and Anti-Vaccinators had differentiated profiles. Furthermore, the predicted probability for belonging to one of these groups showed an inverted shape in the case of "Vaccines Not Important" (Figure A1), "Infec- 
tious Diseases Kill” (Figure A2), "Vaccines Informed" (Figure A3), "Vaccine Knowledge" (Figure A5), "'Self Vaccinated" (Figure A8), "European Vaccination Programs" (Figure A9), "Health System Info" (Figure A12), and "International Vaccination Programs" (Figure A14). Self-Hesitants shared with Anti-Vaccinators the aforementioned reversed profile with Pro-Vaccinators in the case of "Infectious Diseases Kill" (Figure A2), "Vaccines Informed" (Figure A3), "Self Vaccinated" (Figure A8) and "Health System Info" (Figure A12). Moreover, this inverted predicted probability profile between Self-Hesitants and Pro-Vaccinators was also present in the variables "Children Vaccinated" (Figure A4) and "Online Media Info" (Figure A10). Illiterate-Hesitants depicted their main differential characteristic with Pro-Vaccinators in the variable "Vaccination Lack of Knowledge" (Figure A6). The main portrayed difference between Uninformed Anti-Vaccinators and Pro-Vaccinators arose in the component "Information Insecurity" (Figure A7). Social-Hesitants and Pro-Vaccinators differed markedly in "Family and Friends Info" (Figure A11). Finally, the main differential characteristic between Alternative-Hesitants and Pro-Vaccinators rose in 'Other Sources Info' (Figure A13). These results corroborated the findings commented when previously describing the behavioral segments' profiles in Figure 1.

\section{Discussion}

In the previous section, we have presented results that allow answering the two main research questions proposed. First, based on vaccination attitudes, beliefs and behaviors there exist seven different homogeneous segments across the European countries. These pan-European segments are differentiable and actionable.

In a recent report based on a descriptive analysis of the same survey that we used in this paper, the European Commission stated that "... While in general Europeans have a reasonably high level of awareness and a generally positive attitude towards vaccination, there is considerable variation in knowledge and behavior across countries and between socio-demographic groups" [42] (p. 59). The results in the previous section of this paper depicted that cross-European segments based on attitudes towards vaccination existed. When European countries were considered in order to see if there were any significant variation between them in the segments obtained, we concluded that it was not the case. The geographical differences found by the European Commission could be rather linked to the different proportions in which the cross-European segments were represented in each of the member countries than the non-existence of these homogeneous groups. It can be graphically appreciated in Figure 2. It shows a MOSAIC chart [43] that can be interpreted, in a two-way table, as a grouped bar chart where the width of each bar corresponds to the relative frequencies of the first variable (number of interviews per country) and the height of each bar shows the relative frequencies of the second variable (European segments towards vaccination). Standardized residuals are represented in the chart by shadowing the tiles: those that exceed values 2 and 4 in absolute terms are deep-colored. When it occurs, it means that the found pattern departures from the Equiprobability model (independence between the variables). Statistically speaking, it means that, as the standardized residuals are approximately unit-normal $\mathrm{N}(0,1)$, the shadowed areas are those whose individual residuals are significant at 0.05 level (when the value exceeds 2) and 0.0001 level (when the value exceeds 4) [44]. For the shake of clarity, we observe in Figure 2 that Pro-Vaccinators had a statistically significant higher presence in Belgium, the Netherlands, the United Kingdom, Spain, Portugal, Finland, Sweden, Malta, and Slovenia. On the contrary, ProVaccinators showed a statistically significant lower presence in Austria, Czech Republic, Estonia, Latvia, Poland, Slovenia, Bulgaria, Romania, and Croatia. On the other side of the attitudes' spectrum, Anti-Vaccinators had a statistically significantly higher presence in France, Luxembourg, Austria, Czech Republic, Estonia, Latvia, Lithuania, Bulgaria, Romania, and Croatia. In contrast, Belgium, the Netherlands, Denmark, Spain, Portugal, Finland, Sweden, Hungary, and Poland had a statistically significantly lower presence of Anti-Vaccinators. The rest of the segments and countries could be distinctly exhibited in Figure 2. The differences observed by the European Commission between European 
countries in their descriptive analysis are due to the different share that the seven crossEuropean segments had in each of the territories. Nevertheless, the profile of any of the individuals that belong to a segment remains homogeneous to the rest of the individuals that also pertain to the same segment, independently of the European country under study.

The seven segments obtained overcome the traditional pro-vaccine versus anti-vaccine approach. Between these two extreme poles, five other vaccine-hesitant behaviors were found. As we have seen, the individuals that comprised these segments can retard, be averse but still uptake, or decline some or all vaccines. Furthermore, the process followed to obtain the segments avoided the negative connotations associated with the terms "antivaccine" and "vaccine-hesitant". When conducting research about vaccine hesitancy we have to take into account that even those individuals that present the most radical profile do not recognize themselves as "anti-vaccine" [45]. Thus, in the survey that we used, the individuals were first asked about beliefs, attitudes, and behaviors about vaccines and vaccination, and then, after applying sound statistical techniques, we found the segments that were labeled taking into account their different profiles.

From the private companies' management perspective, the findings presented are important. Infectious diseases are global by their nature, mostly in a global economy characterized by a continuous flow of goods and persons between countries. The pharmacy industry and vaccines are also global [46]. Therefore, only if different client behaviors exist that are profitable for the private companies to fulfill with adapted marketing strategies, it would be justified not to follow a Global Marketing Strategy (GMS) approach. Nowadays, for instance, there is more convergence in demand for newer vaccine types and more divergence in demand for mature and combination vaccine types. For the latter ones, adaptations to existing vaccine presentations and packaging are required and increasingly requested. Manufacturers benefit from these distinct presentations, as they prevent parallel trade between high-income countries and low-income countries enable manufacturers to pursue multiple pricing strategies. The existence of cross-European vaccination segments offers additional evidence for private companies when deciding on the continuum that goes from the full standardization to the full adaptation of marketing strategy.

For social marketers (v.gr. European Commission, International Health Organizations, governments, and health authorities), behavioral segmentation is key for success when choosing the target audience and developing different marketing strategies for selected population segments. Social marketing has been long employed in designing, implementing, and evaluating public health programs in the fight against several forms of communicable diseases [47-49]. Moreover, the GMS approach remains valid: adaptation is mainly recommended when there are behavioral differences between the segments that when taken into action produce better results. Our Bayesian multilevel multinomial analysis showed that there were no statistically significant differences for the clusters when considering the 28 countries that formed the European Union. Hence, public organizations that apply a standardized marketing strategy across countries will obtain better outcomes [17,23-25]. The Anti-Vax industry is applying these standardized marketing strategies in their disinformation campaigns obtaining better results than the public institutions that are fighting against them with adapted marketing actions [50]. 




Pro-vaccinators

Self-hesitants

social hesitants

anti-vaccinators

Alternative hesitants

IIIiterate hesitants

Uninformed anti-vaccinators
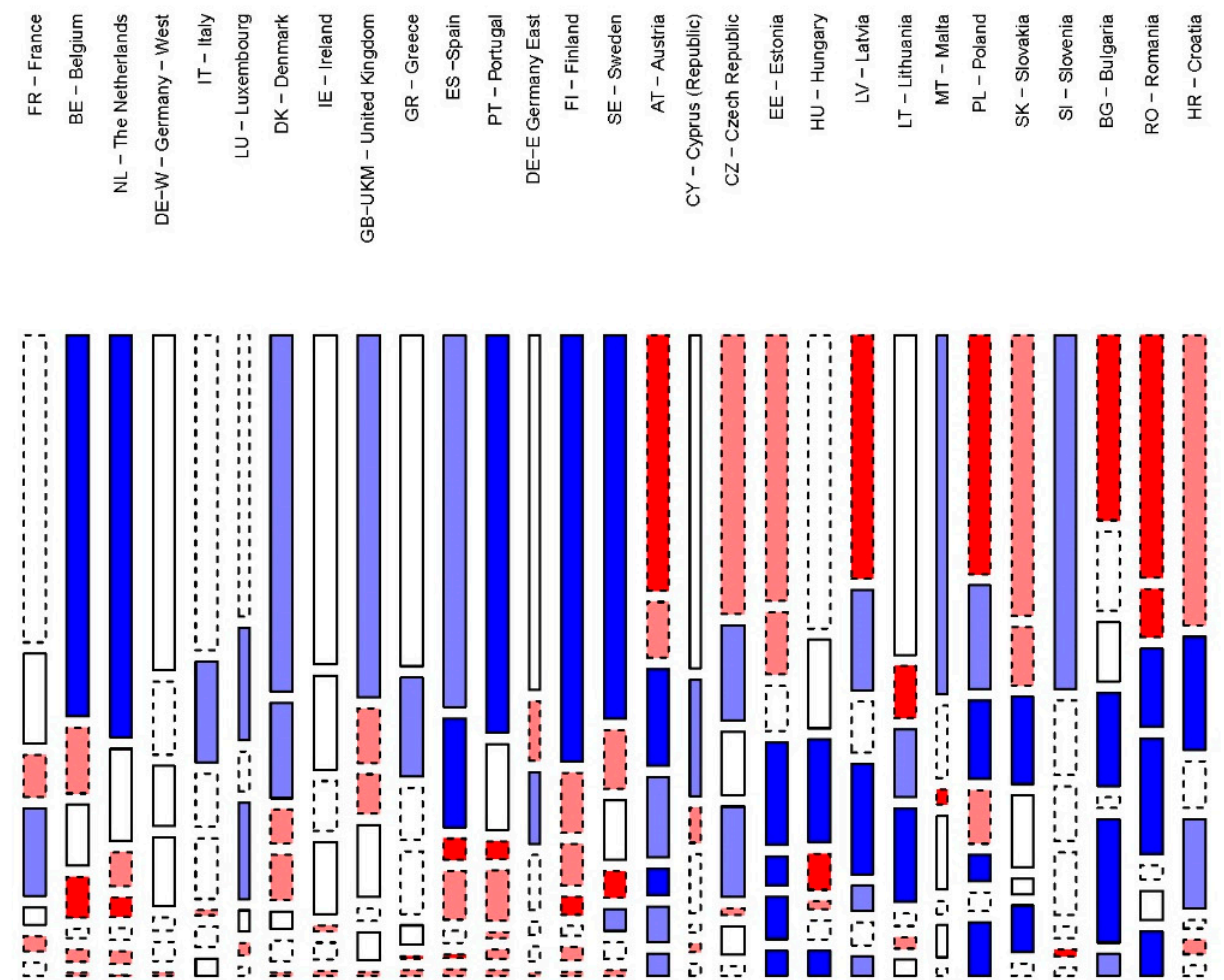

\section{Countries}

Figure 2. European Attitudes Towards Vaccination. Segments by Country.
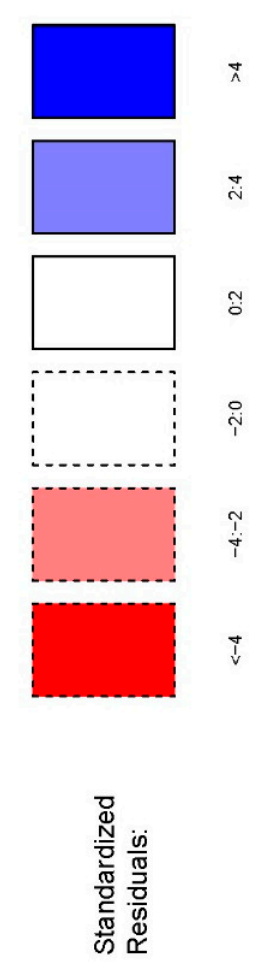
Information is key in both the understanding of the vaccine up-taking decision process and the characterization of the different segments around vaccination. From the results obtained, we noticed that the components related to the different sources of information summed up the highest proportion of the total variance explained (23\%). From Table A1 we knew that the most trusted source of information was a general practitioner, a doctor, or a pediatrician $(79.1 \%$ of the total responses). Several investigations showed that a significant share of health care providers is vaccine-hesitant [51-55]. Even though few health care providers are openly against vaccines, many of them find conversations about vaccines with vaccine-hesitant people to be difficult and unproductive [52]. This has to be a matter of concern for public health authorities. The results of our research also showed that some segments declare a lack of knowledge around vaccines and/or vaccination (Uninformed Anti-Vaccinators and Social-Hesitants). Fighting against the lack of knowledge has to be a priority as a starting point. Nevertheless, lessening the growth of vaccine hesitancy requires not only to communicate information about vaccine efficacy and safety but engaging with the problems expressed by the citizens in an empathically two-way communication strategy [56,57]. Furthermore, it also means sending the tailored messages through the right communication channels. As we saw in the Results section, Pro-Vaccinators and IlliterateHesitants preferred the Health system info, Self-Hesitants and Anti-Vaccinators favored social media Info, Social-Hesitants chose their relatives as the main information source, Alternative-Hesitants indicated other sources of information and, finally, Uninformed Anti-Vaccinators felt such high insecurity about the information received that they did not place trust in any source of information.

Trust in international organizations positively influences people's willingness to adopt recommended behavior $[58,59]$. As we saw, the level of trust in the international organizations to carry on the vaccination programs varied among segments. Pro-vaccinators trusted in European as well as international organizations for managing vaccination programs. Self-Hesitants and Alternative-Hesitants preferred the European ones. Reversely, Social-Hesitants and Uninformed Anti-Vaccinators favored International Organizations. Anti-Vaccinators and Illiterate-Hesitants did not trust any international organization in the management of the vaccination programs, mainly the European ones. Therefore, depending on the target audience, the source of the tailored communication campaign has to be adequately selected to be trusted.

Once that we know that global vaccine hesitancy segments exist across, Europe some other challenges arise. For instance, in Europe immunization programs are a national competence with vaccination schedules that vary across the different territories. We face the GMS dilemma of global consumers with local organizations. The European Commission and the Member States need to put in place coordinated operational guidelines for overcoming infrastructural and legal barriers through more standardized vaccination management. In this regard, two European initiatives taken in 2018 [11,60] accomplished an actions' framework that was undertaken by the Commission, with the collaboration of the Member States, under three key pillars: (1) tackling vaccine hesitancy and improving vaccination coverage; (2) sustainable vaccination policies in the EU; (3) EU coordination of and contribution to global health. The roadmap for the implementation of actions contained in these two European initiatives fixes several challenges that a global social marketing strategy for reducing vaccine hesitancy must face because immunization programs are a national competence.

Finally, more study is required to understand the effect that age, gender, family status, occupation, education, type of community where the person lives, political orientation, and religion have in the cross-European segments found and the proposed GMS strategy.

Author Contributions: Conceptualization, A.R.-R., M.R.-M. and M.V.R.-G.; methodology, A.R.-R., M.R.-M. and M.V.R.-G.; literature review, A.R.-R.; software, A.R.-R.; validation, A.R.-R.; formal analysis, A.R.-R.; investigation, A.R.-R.; data curation, A.R.-R.; writing the original draft, A.R.-R.; review and editing the manuscript, M.R.-M. and M.V.R.-G. All authors have read and agreed to the published version of the manuscript. 
Funding: This research received no external funding.

Institutional Review Board Statement: Not applicable.

Informed Consent Statement: Not applicable.

Data Availability Statement: Publicly available datasets were analyzed in this study. This data can be found through GESIS (University of Cologne, Germany) at https://www.gesis.org/en/ eurobarometer-data-service/search-data-access/data-access.

Acknowledgments: We gratefully acknowledge the support of GESIS (University of Cologne, Germany) for providing access to the Eurobarometer dataset.

Conflicts of Interest: The authors declare no conflict of interest.

\section{Appendix A}

Table A1. Sample descriptives.

\begin{tabular}{|c|c|c|c|c|}
\hline Variable $\#^{1}$ & Variable & Response Categories & $n$ & Sample Share \\
\hline qc1 & $\begin{array}{l}\text { Diseases causing } \\
\text { deaths in the EU } \\
\text { nowadays }\end{array}$ & $\begin{array}{c}\text { Flu } \\
\text { Measles } \\
\text { Polio } \\
\text { Hepatitis } \\
\text { Meningitis } \\
\text { Tetanus } \\
\text { None of them } \\
\text { Don't Know (DK) }\end{array}$ & $\begin{array}{c}16,464 \\
10,547 \\
4808 \\
11,323 \\
14,190 \\
6315 \\
2348 \\
1728 \\
\end{array}$ & $\begin{array}{l}59.8 \\
38.3 \\
17.5 \\
41.1 \\
51.6 \\
22.9 \\
8.5 \\
6.3 \\
\end{array}$ \\
\hline $\mathrm{qc} 2$ & Vaccines effective & $\begin{array}{c}\text { Yes, definitely } \\
\text { Yes, probably } \\
\text { No, probably not } \\
\text { No, not at all } \\
\text { It depends on the disease } \\
\text { Don't Know (DK) }\end{array}$ & $\begin{array}{c}13,972 \\
9450 \\
1664 \\
870 \\
1011 \\
557\end{array}$ & $\begin{array}{c}50.8 \\
34.3 \\
6 \\
3.2 \\
3.7 \\
2\end{array}$ \\
\hline qc3 & $\begin{array}{l}\text { Vaccinations in family } \\
\text { last five years }\end{array}$ & $\begin{array}{c}\text { Yes, yourself } \\
\text { Yes, your children } \\
\text { Yes, someone else } \\
\text { No } \\
\text { Don't Know (DK) }\end{array}$ & $\begin{array}{c}11,820 \\
7164 \\
5521 \\
9683 \\
315\end{array}$ & $\begin{array}{c}42.9 \\
26 \\
19.1 \\
35.2 \\
1.1\end{array}$ \\
\hline qc6 & Have vaccination card & $\begin{array}{c}\text { Yes, for yourself } \\
\text { Yes, for your children } \\
\text { No } \\
\text { Don't Know (DK) }\end{array}$ & $\begin{array}{c}11,754 \\
6813 \\
11,978 \\
651\end{array}$ & $\begin{array}{c}42.7 \\
24.8 \\
43.5 \\
2.4\end{array}$ \\
\hline qc7_1 & $\begin{array}{l}\text { Vaccines affect the } \\
\text { immune system }\end{array}$ & $\begin{array}{c}\text { TRUE } \\
\text { FALSE } \\
\text { Do not Know (DK) }\end{array}$ & $\begin{array}{c}8849 \\
14,461 \\
4214\end{array}$ & $\begin{array}{l}32.2 \\
52.5 \\
15.3\end{array}$ \\
\hline qc7_2 & Vaccines cause diseases & $\begin{array}{c}\text { TRUE } \\
\text { FALSE } \\
\text { Don't Know (DK) } \\
\end{array}$ & $\begin{array}{c}10,669 \\
13,066 \\
3789 \\
\end{array}$ & $\begin{array}{l}38.8 \\
47.5 \\
13.8 \\
\end{array}$ \\
\hline qc7_3 & Vaccines side-effects & $\begin{array}{c}\text { TRUE } \\
\text { FALSE } \\
\text { Don't Know (DK) }\end{array}$ & $\begin{array}{c}13,617 \\
10,735 \\
3172\end{array}$ & $\begin{array}{c}49.5 \\
39 \\
11.5\end{array}$ \\
\hline qc7_4 & Vaccines tested & $\begin{array}{c}\text { TRUE } \\
\text { FALSE } \\
\text { Don't Know (DK) }\end{array}$ & $\begin{array}{c}21,884 \\
2736 \\
2904\end{array}$ & $\begin{array}{c}79.5 \\
9.9 \\
10.6\end{array}$ \\
\hline qc8_1 & $\begin{array}{l}\text { Routine vaccination } \\
\text { important }\end{array}$ & $\begin{array}{l}\text { Totally agree } \\
\text { Tend to agree } \\
\text { Tend to disagree } \\
\text { Totally disagree } \\
\text { Don't Know (DK) }\end{array}$ & $\begin{array}{l}14,222 \\
8776 \\
2670 \\
890 \\
966\end{array}$ & $\begin{array}{l}51.7 \\
31.9 \\
9.7 \\
3.2 \\
3.5\end{array}$ \\
\hline
\end{tabular}


Table A1. Cont.

\begin{tabular}{|c|c|c|c|c|}
\hline Variable \# 1 & Variable & Response Categories & $n$ & Sample Share \\
\hline \multirow{5}{*}{ qc8_2 } & \multirow{5}{*}{$\begin{array}{l}\text { Vaccines only for } \\
\text { children }\end{array}$} & Totally agree & 3643 & 13.2 \\
\hline & & Tend to agree & 4551 & 16.5 \\
\hline & & Tend to disagree & 8351 & 30.3 \\
\hline & & Totally disagree & 10,270 & 37.3 \\
\hline & & Don't Know (DK) & 709 & 2.6 \\
\hline \multirow{5}{*}{ qc8_3 } & \multirow{5}{*}{$\begin{array}{l}\text { Not vaccinated serious } \\
\text { health issues }\end{array}$} & Totally agree & 13,065 & 47.5 \\
\hline & & Tend to agree & 9371 & 34 \\
\hline & & Tend to disagree & 3008 & 10.9 \\
\hline & & Totally disagree & 932 & 3.4 \\
\hline & & Don't Know (DK) & 1148 & 4.2 \\
\hline \multirow{5}{*}{ qc8_4 } & \multirow{5}{*}{$\begin{array}{l}\text { Vaccines' importance } \\
\text { for self and others }\end{array}$} & Totally agree & 15,284 & 55.5 \\
\hline & & Tend to agree & 8956 & 32.5 \\
\hline & & Tend to disagree & 1819 & 6.6 \\
\hline & & Totally disagree & 577 & 2.1 \\
\hline & & Don't Know (DK) & 888 & 3.2 \\
\hline \multirow{5}{*}{ qc8_5 } & \multirow{5}{*}{$\begin{array}{l}\text { Vaccines' importance } \\
\text { for non-vaccinated }\end{array}$} & Totally agree & 14,505 & 52.7 \\
\hline & & Tend to agree & 9296 & 33.8 \\
\hline & & Tend to disagree & 1786 & 6.5 \\
\hline & & Totally disagree & 598 & 2.2 \\
\hline & & Don't Know (DK) & 1339 & 4.9 \\
\hline \multirow{11}{*}{ qc9 } & \multirow{11}{*}{ Vaccine info sources } & Family & 2627 & 9.5 \\
\hline & & Friends & 1351 & 4.9 \\
\hline & & $\begin{array}{c}\text { Your general practitioner, a doctor, or } \\
\text { a pediatrician }\end{array}$ & 21,765 & 79.1 \\
\hline & & $\begin{array}{c}\text { Other health care workers (nurses, } \\
\text { specialist doctors, etc.) }\end{array}$ & 8647 & 31.4 \\
\hline & & Pharmacists & 5103 & 18.5 \\
\hline & & Online social networks & 1632 & 5.9 \\
\hline & & Other Internet sites & 3539 & 12.9 \\
\hline & & The health authorities & 7570 & 27.5 \\
\hline & & Other (SPONTANEOUS) & 298 & 1.1 \\
\hline & & None (SPONTANEOUS) & 504 & 1.8 \\
\hline & & Don't Know (DK) & 238 & 0.9 \\
\hline \multirow{11}{*}{ qc10 } & \multirow{11}{*}{$\begin{array}{l}\text { Most trusted vaccine } \\
\text { info source }\end{array}$} & Family & 845 & 3.1 \\
\hline & & Friends & 355 & 1.3 \\
\hline & & $\begin{array}{l}\text { Your general practitioner, a doctor, or } \\
\text { a pediatrician }\end{array}$ & 17,521 & 63.7 \\
\hline & & $\begin{array}{l}\text { Other health care workers (nurses, } \\
\text { specialist doctors, etc.) }\end{array}$ & 2695 & 9.8 \\
\hline & & Pharmacists & 928 & 3.4 \\
\hline & & Online social networks & 285 & 1 \\
\hline & & Other Internet sites & 553 & 2 \\
\hline & & The health authorities & 3323 & 12.1 \\
\hline & & Other (SPONTANEOUS) & 74 & 0.3 \\
\hline & & None (SPONTANEOUS) & 576 & 2.1 \\
\hline & & Don't Know (DK) & 369 & 1.3 \\
\hline \multirow{5}{*}{ qc11 } & \multirow{5}{*}{$\begin{array}{l}\text { Vaccine programs' } \\
\text { coordination level }\end{array}$} & At international level & 8911 & 32.4 \\
\hline & & At European level & 8399 & 30.5 \\
\hline & & At a national level & 4526 & 42.4 \\
\hline & & $\begin{array}{l}\text { At regional or local level } \\
\text { There should be no vaccination }\end{array}$ & 2512 & 9.1 \\
\hline & & $\begin{array}{c}\text { programs, it is a personal choice } \\
\text { Don't Know (DK) }\end{array}$ & 1305 & 4.7 \\
\hline \multirow{8}{*}{ qc12 } & \multirow{8}{*}{$\begin{array}{l}\text { Media info on vaccine } \\
\text { last six months }\end{array}$} & No & 8052 & 29.3 \\
\hline & & Yes, on TV & 15,447 & 56.1 \\
\hline & & Yes, on the radio & 4775 & 17.3 \\
\hline & & Yes, in newspapers or magazines & 5771 & 21 \\
\hline & & Yes, on online social networks & 3571 & 13 \\
\hline & & Yes, on other Internet sites & 2835 & 10.3 \\
\hline & & Other (SPONTANEOUS) & 433 & 1.6 \\
\hline & & Don't Know (DK) & 490 & 1.8 \\
\hline
\end{tabular}

${ }^{1}$ We kept the question number used in the Eurobarometer in order to be easily identifiable in the original questionnaire codebook. Source: Eurobarometer 91.2. European Commision [30]. 


\section{Appendix B}

Table A2. PCA components loadings (VARIMAX rotation).

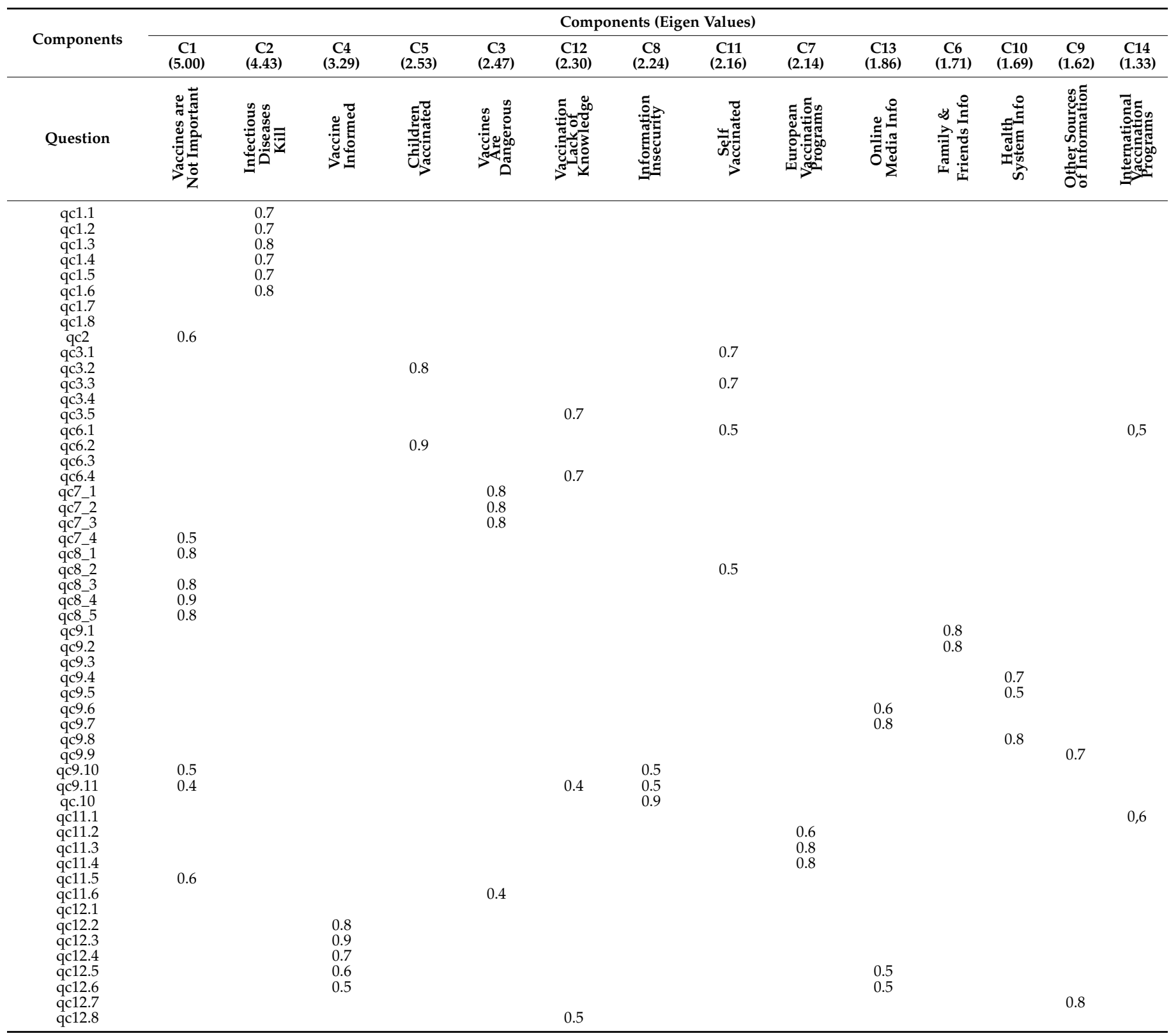




\section{Appendix C}

Table A3. ANOVA (Tukey HSD). Segments' mean differences.

\begin{tabular}{|c|c|c|c|c|c|c|c|}
\hline $\begin{array}{c}\text { Title } \\
\text { Vaccine-Hesitancy Segments }\end{array}$ & 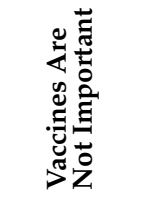 & 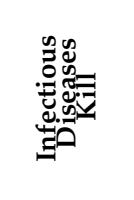 & & 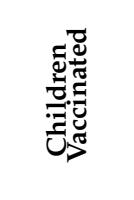 & 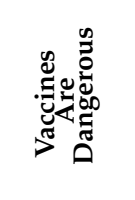 & 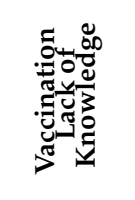 & 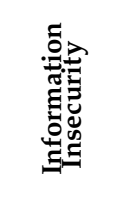 \\
\hline Self-hesitants/Pro-vaccinators & $0.05^{* *}$ & $-0.08^{* * *}$ & -0.03 & $1.82 * * *$ & $0.10^{* * *}$ & 0 & -0.01 \\
\hline Social hesitants/Pro-vaccinators & $0.27^{* * *}$ & 0.02 & 0.04 & $0.28 * * *$ & 0.04 & $-0.12 * * *$ & $0.22 * * *$ \\
\hline Anti-vaccinators/Pro-vaccinators & $1.08 * * *$ & $-0.08^{* * *}$ & -0.04 & $0.32 * * *$ & $0.35^{* * *}$ & $-0.29 * * *$ & $-0.40^{* * *}$ \\
\hline Alternative hesitants/Pro-vaccinators & $0.35 * * *$ & -0.05 & $-0.27 * * *$ & $0.37 * * *$ & 0.05 & $-0.08^{* *}$ & $0.14^{* * *}$ \\
\hline Illiterate hesitants/Pro-vaccinators & $0.40^{* * *}$ & -0.05 & $-0.4^{* * *}$ & $0.24^{* * *}$ & $0.20 * * *$ & $3.00 * * *$ & 0.05 \\
\hline $\begin{array}{c}\text { Uninformed } \\
\text { anti-vaccinators/Pro-vaccinators }\end{array}$ & $1.58^{* * *}$ & $-0.13^{* *}$ & 0.02 & $0.13^{* * *}$ & $0.14^{* *}$ & $-0.67^{* * *}$ & $2.84^{* * *}$ \\
\hline Social hesitants/Self-hesitants & $0.21 * * *$ & $0.09^{* * *}$ & $0.06^{*}$ & $-1.55^{* * *}$ & -0.06 & $-0.12^{* * *}$ & $0.23 * * *$ \\
\hline Anti-vaccinators/Self-hesitants & $1.03 * * *$ & 0.00 & -0.01 & $-1.5^{* * *}$ & $0.25^{* * *}$ & $-0.29 * * *$ & $-0.39 * * *$ \\
\hline Alternative hesitants/Self-hesitants & $0.30 * * *$ & 0.03 & $-0.24^{* * *}$ & $-1.45^{* * *}$ & -0.05 & $-0.08 *$ & $0.15^{* * *}$ \\
\hline Illiterate hesitants/Self-hesitants & $0.35^{* * *}$ & 0.03 & $-0.37^{* * *}$ & $-1.59^{* * *}$ & 0.10 * & $3.00 * * *$ & 0.06 \\
\hline Uninformed anti-vaccinators/Self-hesitants & $1.53^{* * *}$ & -0.05 & 0.05 & $-1.69^{* * *}$ & 0.04 & $-0.67^{* * *}$ & $2.85^{* * *}$ \\
\hline Anti-vaccinators/Social hesitants & $0.82^{* * *}$ & $-0.09^{* * *}$ & $-0.08 * *$ & 0.04 & $0.31^{* * *}$ & $-0.16^{* * *}$ & $-0.62^{* * *}$ \\
\hline Alternative hesitants/Social hesitants & 0.08 & -0.06 & $-0.31 * * *$ & 0.09 & 0.01 & 0.04 & -0.09 \\
\hline Illiterate hesitants-Social hesitants & $0.14^{* * *}$ & -0.07 & $-0.44^{* * *}$ & -0.04 & 0.16 & $3.13^{* * *}$ & $-0.17 * * *$ \\
\hline $\begin{array}{l}\text { Uninformed anti-vaccinators/Social } \\
\text { hesitants }\end{array}$ & $1.32 * * *$ & $-0.14^{* * *}$ & -0.02 & $-0.15^{* * *}$ & 0.1 & $-0.55^{* * *}$ & $2.61^{* * *}$ \\
\hline Alternative hesitants / Anti-vaccinators & $-0.073^{* * *}$ & 0.03 & $-0.23^{* * *}$ & 0.05 & $-0.30^{* * *}$ & $0.20^{* * *}$ & $0.53^{* * *}$ \\
\hline Illiterate hesitants-Anti-vaccinators & $-0.68 * * *$ & 0.02 & $-0.36 * * *$ & $-0.08 *$ & $-0.15^{* * *}$ & $3.29 * * *$ & $0.45^{* * *}$ \\
\hline $\begin{array}{l}\text { Uninformed } \\
\text { anti-vaccinators/Anti-vaccinators }\end{array}$ & $0.50 * * *$ & -0.05 & 0.06 & $-0.19 *$ & $-0.21^{* * *}$ & $-0.38 * * *$ & $3.23^{* * *}$ \\
\hline Illiterate hesitants / Alternative hesitants & 0.05 & 0.00 & $-0.13 *$ & $-0.13^{* * *}$ & $0.15^{*}$ & $3.08^{* * *}$ & -0.09 \\
\hline $\begin{array}{c}\text { Uninformed anti-vaccinators/Alternative } \\
\text { hesitants }\end{array}$ & $1.23^{* * *}$ & -0.08 & $0.29^{* * *}$ & $-0.24^{* *}$ & 0.09 & $-0.59 * * *$ & $2.70 * * *$ \\
\hline $\begin{array}{l}\text { Uninformed anti-vaccinators/Illiterate } \\
\text { hesitants }\end{array}$ & $1.18^{* * *}$ & -0.08 & $0.42^{* * *}$ & $-0.11^{* * *}$ & -0.06 & $-3.67^{* * *}$ & $2.78^{* * *}$ \\
\hline Self-hesitants/Pro-vaccinators & $-0.34 * * *$ & 0.01 & $0.24 * * *$ & $-0.07^{* * *}$ & $-0.13^{* * *}$ & $-0.04 * * *$ & $-0.14^{* * *}$ \\
\hline Social hesitants/Pro-vaccinators & & $-0.13^{* * *}$ & $-0.23 * * *$ & $2.15^{* * *}$ & $-0.30^{* * *}$ & $-0.04^{* * *}$ & -0.05 \\
\hline Anti-vaccinators/Pro-vaccinators & $-0.14^{* * *}$ & $-1.09^{* * *}$ & $0.06 *$ & $0.05 * * *$ & 0 & $-0.07 * * *$ & $-0.21 * * *$ \\
\hline Alternative hesitants/Pro-vaccinators & -0.04 & -0.07 & $-0.22 * * *$ & $0.34 * * *$ & $-0.13 * *$ & $4.90 * * *$ & -0.11 \\
\hline Illiterate hesitants/Pro-vaccinators & $-0.20^{* * *}$ & $-0.27^{* * *}$ & $0.13^{* * *}$ & $0.28^{* * *}$ & $0.15^{* * *}$ & $-0.06^{* * *}$ & $-0.69 * * *$ \\
\hline $\begin{array}{l}\text { Uninformed } \\
\text { anti-vaccinators/Pro-vaccinators }\end{array}$ & -0.01 & $-0.22^{* * *}$ & $-0.81^{* * *}$ & $-0.59^{* * *}$ & $-1.47^{* * *}$ & $-0.72^{* * *}$ & -0.01 \\
\hline Social hesitants / Self-hesitants & $0.34^{* * *}$ & $-0.14^{* * *}$ & $-0.47^{* * *}$ & $2.23^{* * *}$ & $-0.16^{* * *}$ & 0 & $0.10^{* *}$ \\
\hline Anti-vaccinators/Self-hesitants & $0.20 * * *$ & $-1.10^{* * *}$ & $-0.18^{* * *}$ & $0.13^{* * *}$ & $0.13^{* * *}$ & $-0.03 * *$ & $-0.07 *$ \\
\hline Alternative hesitants/Self-hesitants & $0.30 * * *$ & -0.08 & $-0.46^{* * *}$ & $0.42 * * *$ & 0 & $4.95^{* * *}$ & 0.03 \\
\hline Illiterate hesitants/Self-hesitants & $0.14^{* *}$ & $-0.27^{* * *}$ & $-0.11^{* *}$ & $0.35^{* * *}$ & $0.28^{* * *}$ & -0.02 & $-0.54^{* * *}$ \\
\hline Uninformed anti-vaccinators/Self-hesitants & $0.32 * * *$ & $-0.22^{* * *}$ & $-1.05^{* * *}$ & $-0.51^{* * *}$ & $-1.34^{* * *}$ & $-0.67^{* * *}$ & $0.13 *$ \\
\hline Anti-vaccinators/Social hesitants & $-0.14^{* * *}$ & $-0.96^{* * *}$ & $0.29^{* * *}$ & $-2.10^{* * *}$ & $0.30 * * *$ & -0.04 & $-0.17^{* * *}$ \\
\hline Alternative hesitants/Social hesitants & -0.04 & 0.06 & 0.01 & $-1.81^{* * *}$ & $0.16^{* * *}$ & $4.94^{* * *}$ & -0.06 \\
\hline Illiterate hesitants-Social hesitants & $-0.20 * * *$ & $-0.14^{* * *}$ & $0.35^{* * *}$ & $-1.87^{* * *}$ & $0.45^{* * *}$ & $-0.03^{* *}$ & $-0.64^{* * *}$ \\
\hline $\begin{array}{l}\text { Uninformed anti-vaccinators/Social } \\
\text { hesitants }\end{array}$ & -0.01 & -0.09 & $-0.59^{* * *}$ & $-2.74 * * *$ & $-1.18^{* * *}$ & $-0.68^{* * *}$ & 0.04 \\
\hline Alternative hesitants / Anti-vaccinators & 0.11 & $1.02 * * *$ & $-0.28 * * *$ & $0.29 * * *$ & $-0.13^{* *}$ & $4.98^{* * *}$ & 0.10 \\
\hline Illiterate hesitants-Anti-vaccinators & -0.06 & $0.83 * * *$ & 0.07 & $0.23 * * *$ & $0.15^{* * *}$ & 0.01 & $-0.47^{* * *}$ \\
\hline $\begin{array}{l}\text { Uninformed } \\
\text { anti-vaccinators/Anti-vaccinators }\end{array}$ & 0.13 * & $0.88^{* * *}$ & $-0.87^{* * *}$ & $-0.64^{* * *}$ & $-1.47^{* * *}$ & $-0.64^{* * *}$ & $0.20 * * *$ \\
\hline Illiterate hesitants / Alternative hesitants & $-0.17^{* *}$ & $-0.19^{* * *}$ & $0.35 * * *$ & -0.06 & $0.28^{* * *}$ & $-4.97^{* * *}$ & $-0.58^{* * *}$ \\
\hline $\begin{array}{c}\text { Uninformed anti-vaccinators/Alternative } \\
\text { hesitants }\end{array}$ & 0.02 & $-0.14 *$ & $-0.59^{* * *}$ & $-0.93^{* * *}$ & $-1.34^{* * *}$ & $-5.62 * * *$ & 0.10 \\
\hline $\begin{array}{c}\text { Uninformed anti-vaccinators/Illiterate } \\
\text { hesitants }\end{array}$ & $0.19^{* *}$ & 0.05 & $-0.94^{* * *}$ & $-0.87^{* * *}$ & $-1.63^{* * *}$ & $-0.65^{* * *}$ & $0.68^{* * *}$ \\
\hline
\end{tabular}

Note: ${ }^{*} p<0.05,{ }^{* *} p<0.01,{ }^{* * *} p<0.001$. 


\section{Appendix D}
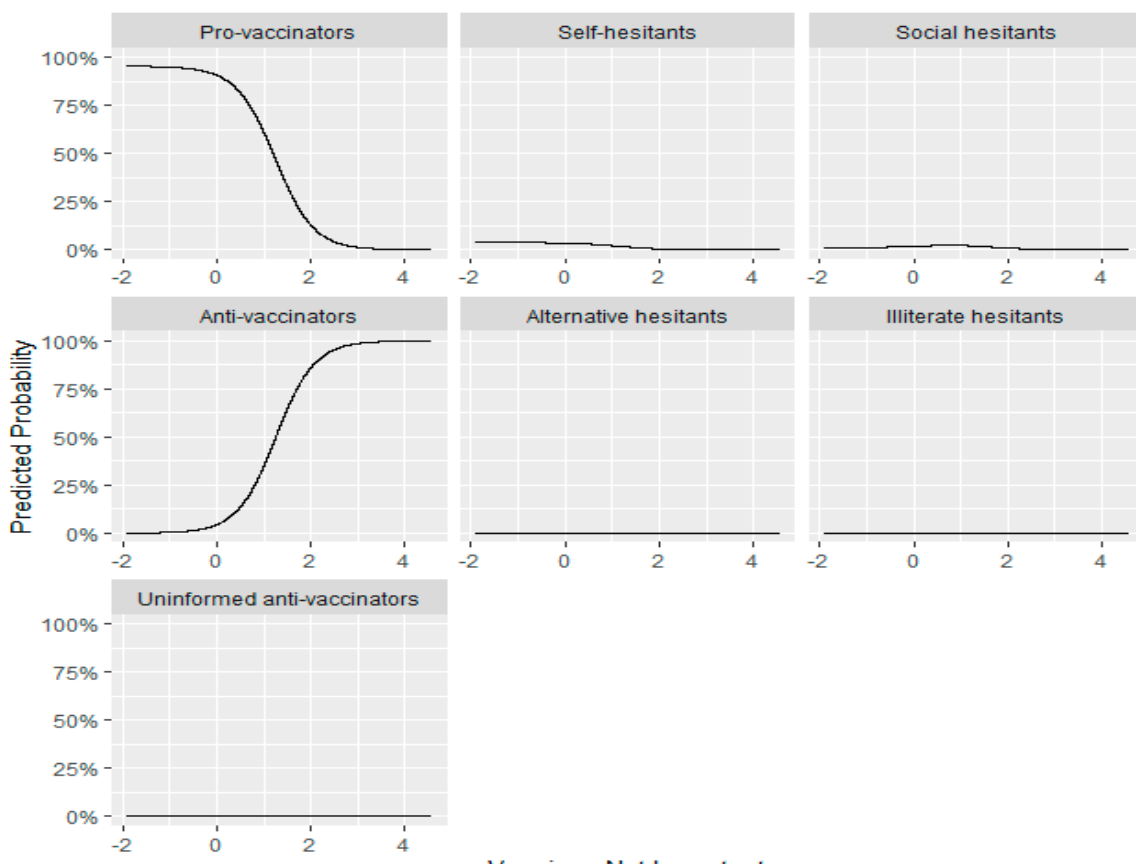

Vaccines Not Important

Figure A1. Marginal Effects Multinomial Logistic Regression. Vaccines Not Important.
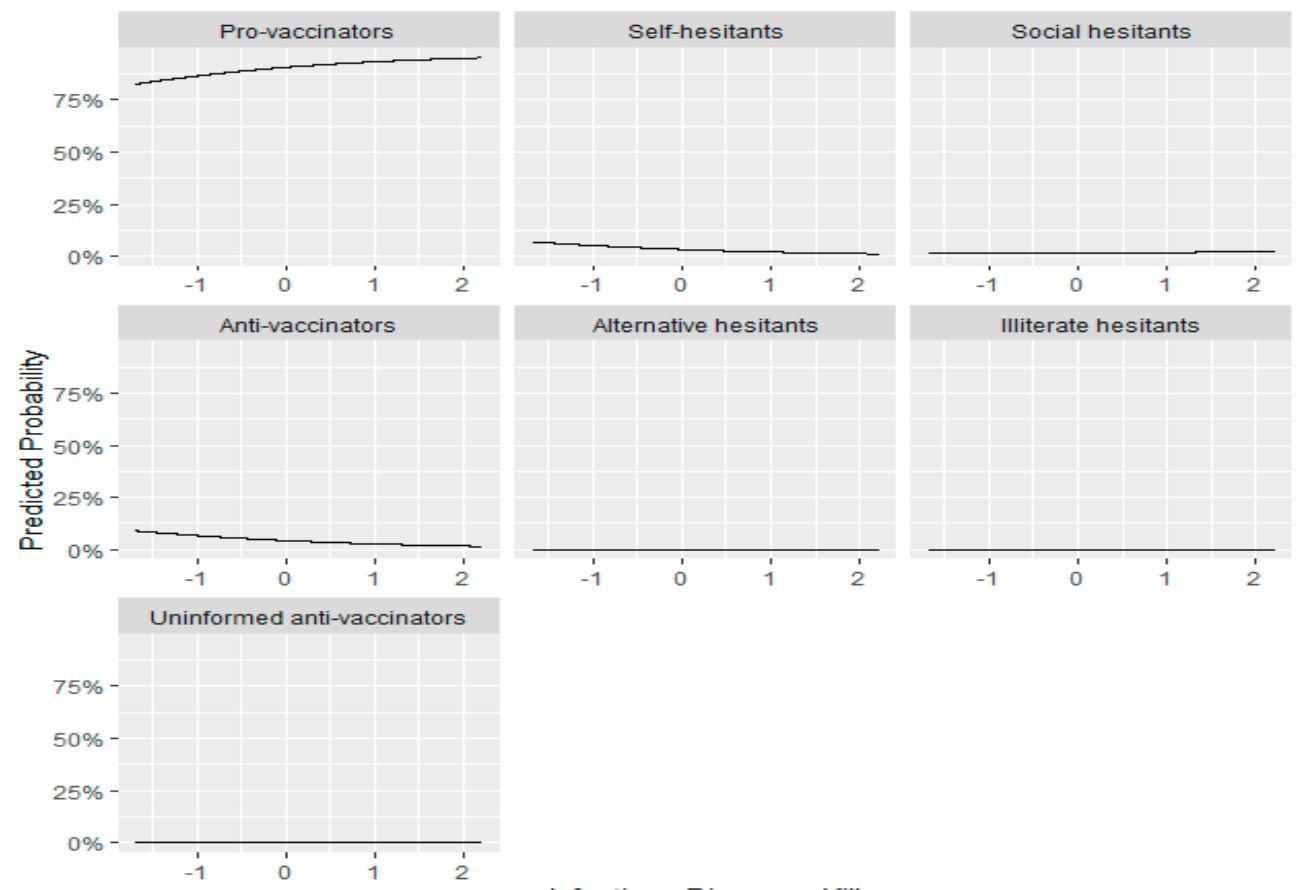

Infectious Diseases Kill

Figure A2. Marginal Effects Multinomial Logistic Regression. Infectious Diseases Kill. 


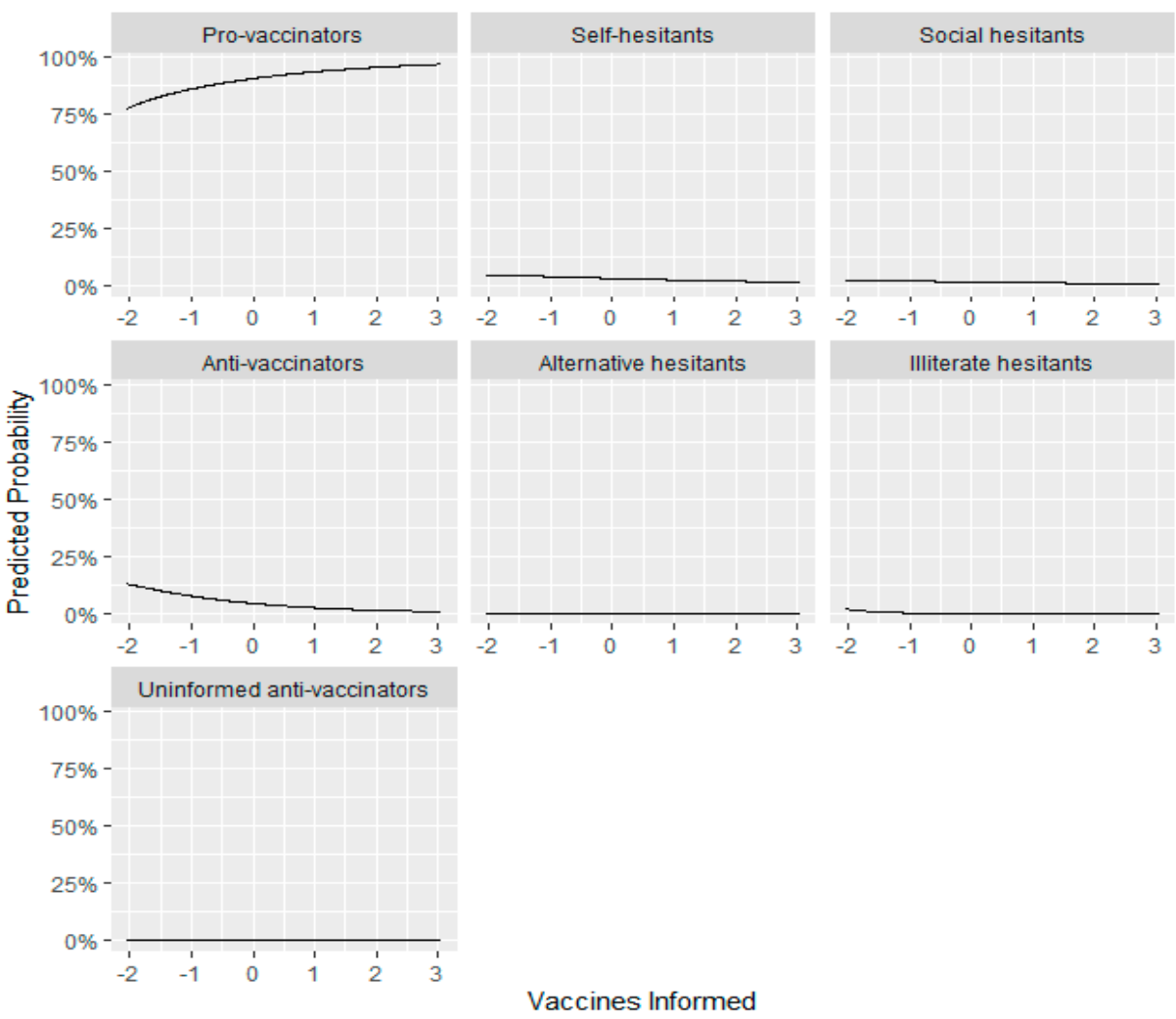

Figure A3. Marginal Effects Multinomial Logistic Regression. Vaccines Informed.
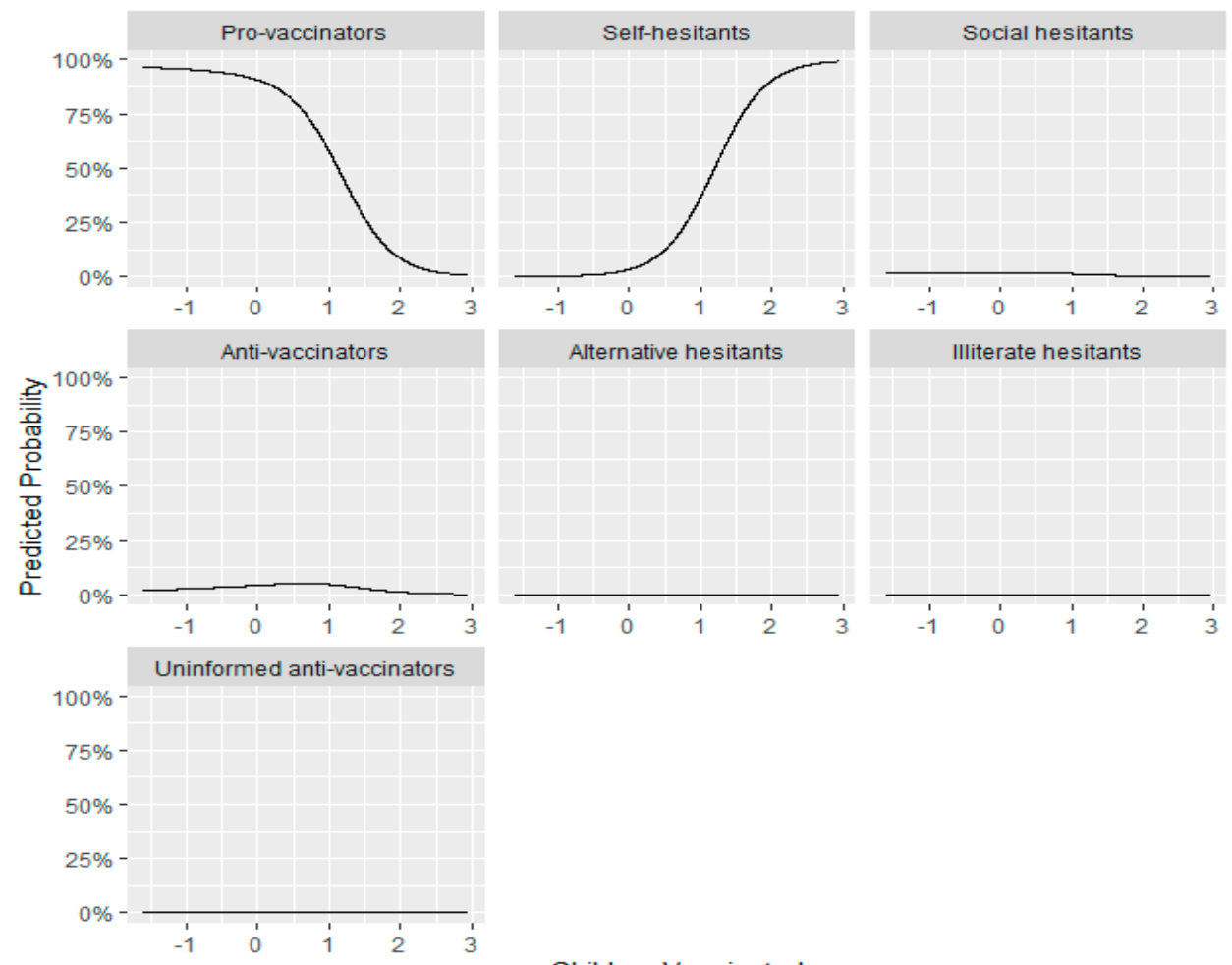

Figure A4. Marginal Effects Multinomial Logistic Regression. Children Vaccinated. 


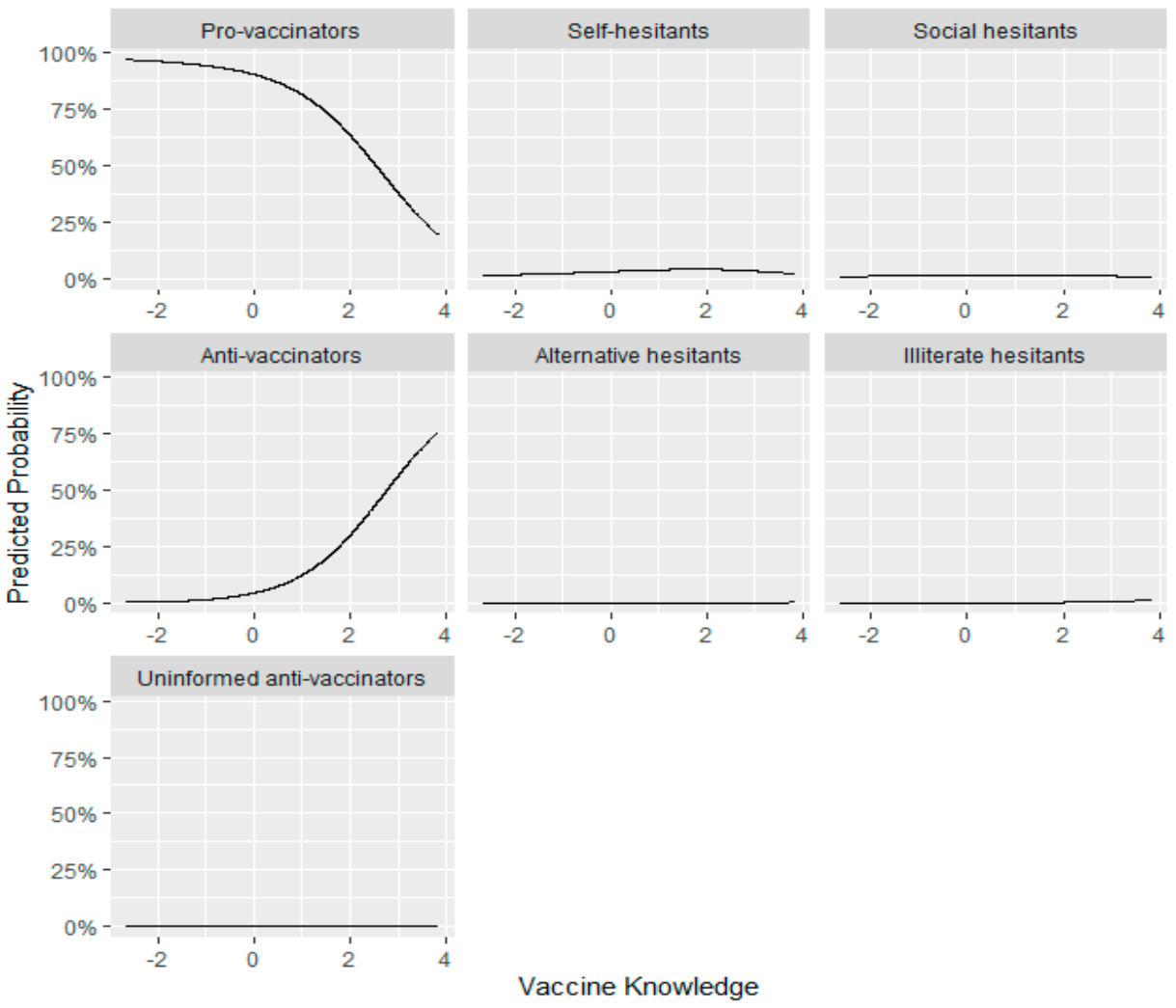

Figure A5. Marginal Effects Multinomial Logistic Regression. Vaccine Knowledge.

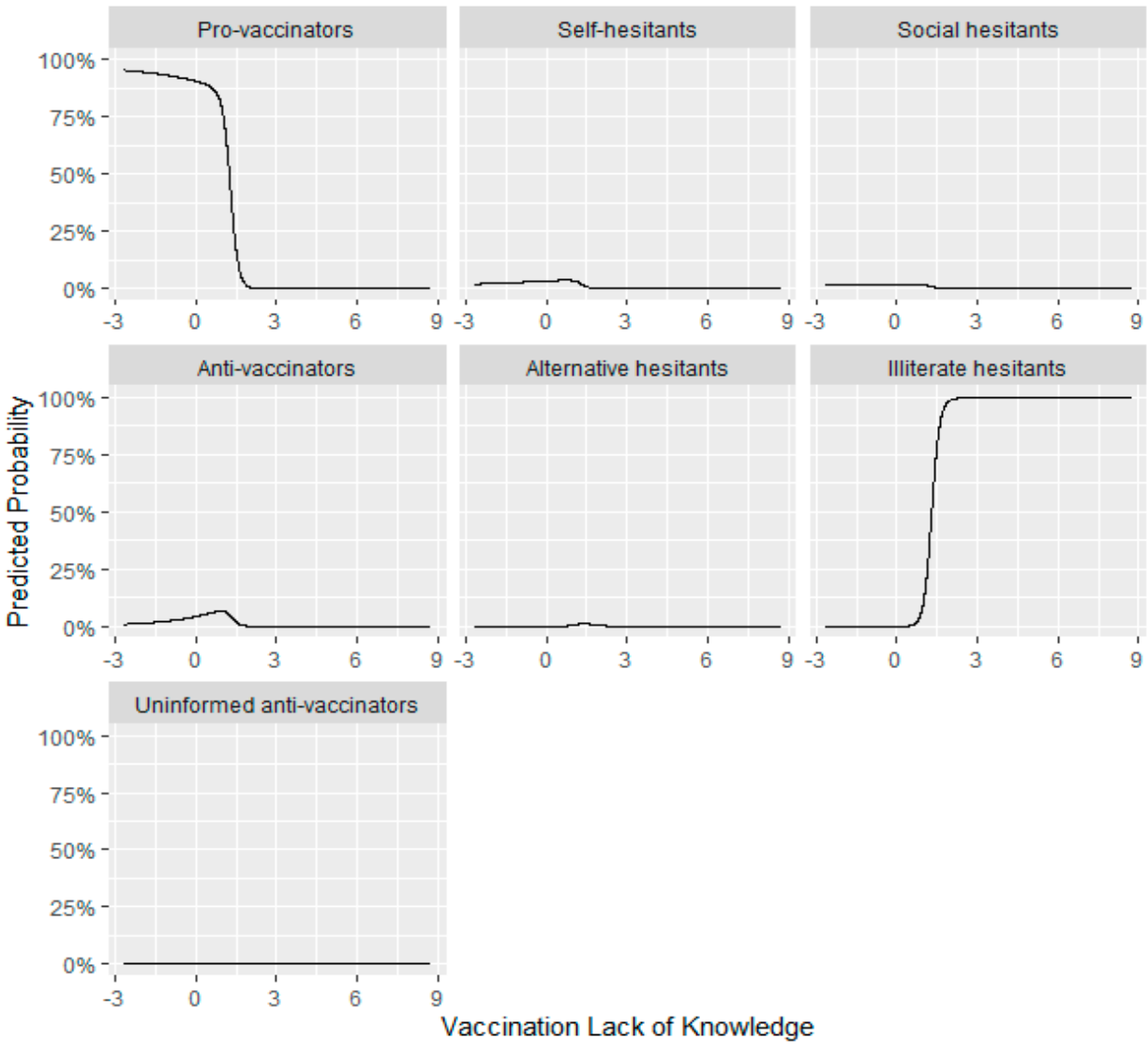

Figure A6. Marginal Effects Multinomial Logistic Regression. Vaccination Lack of Knowledge. 


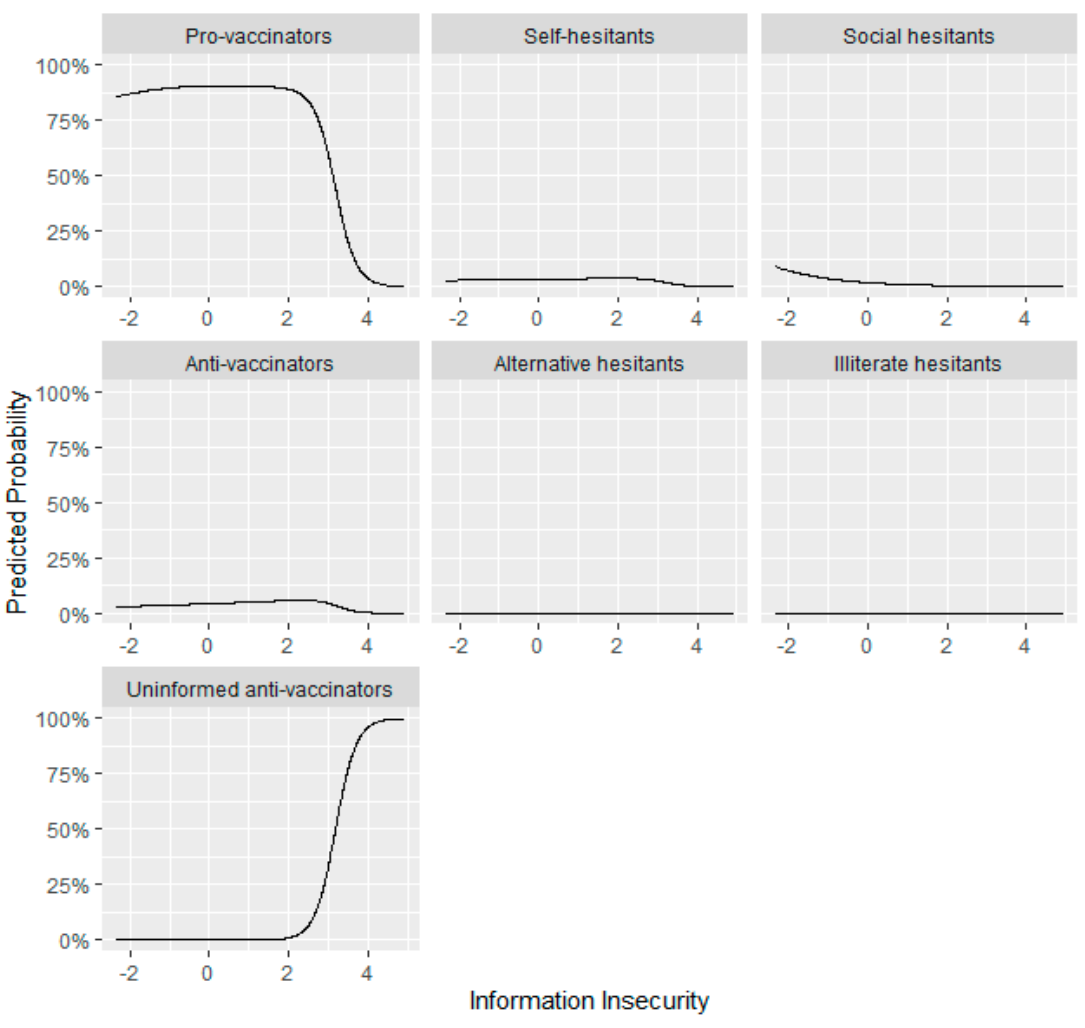

Figure A7. Marginal Effects Multinomial Logistic Regression. Information Insecurity.
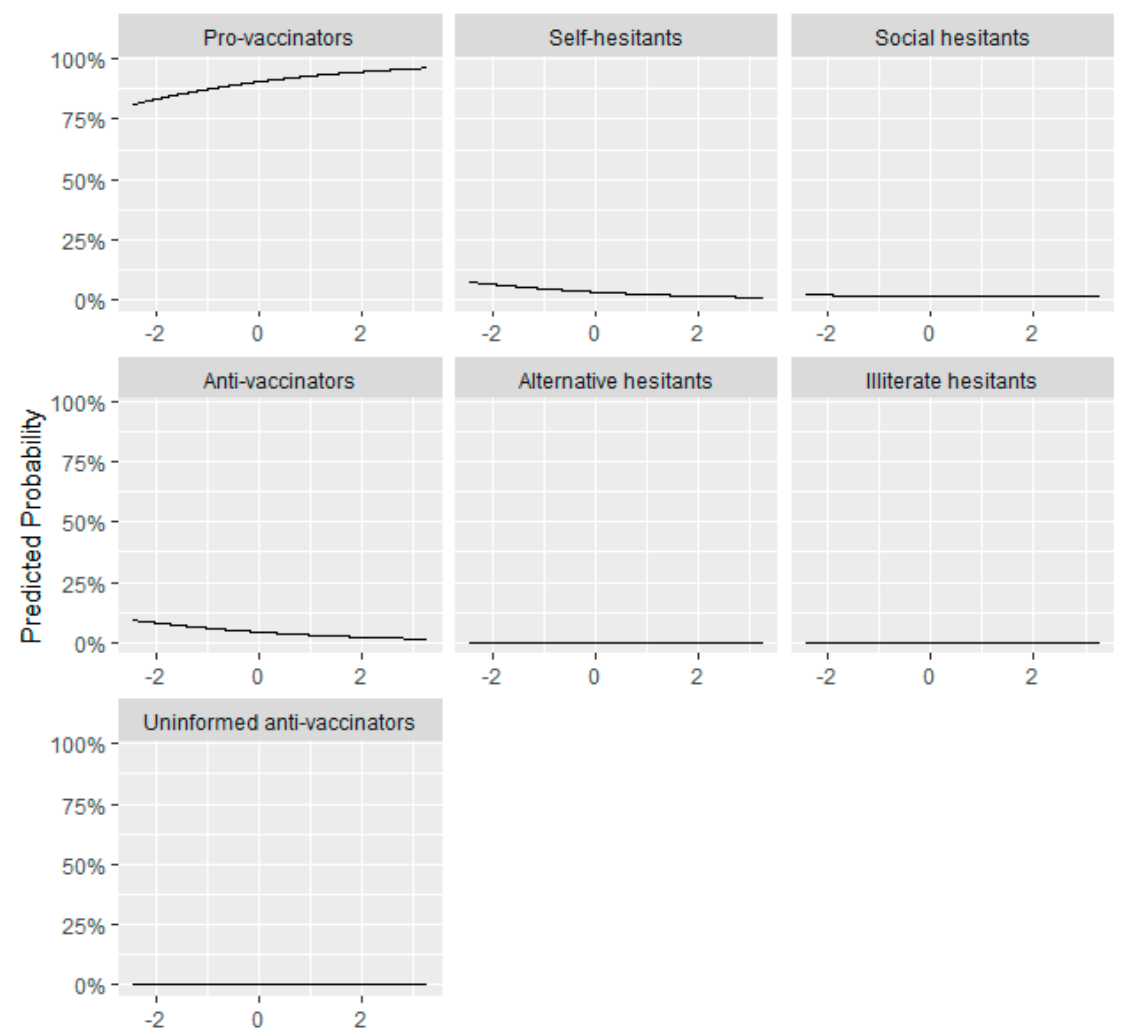

\section{Self Vaccinated}

Figure A8. Marginal Effects Multinomial Logistic Regression. Self Vaccinated. 


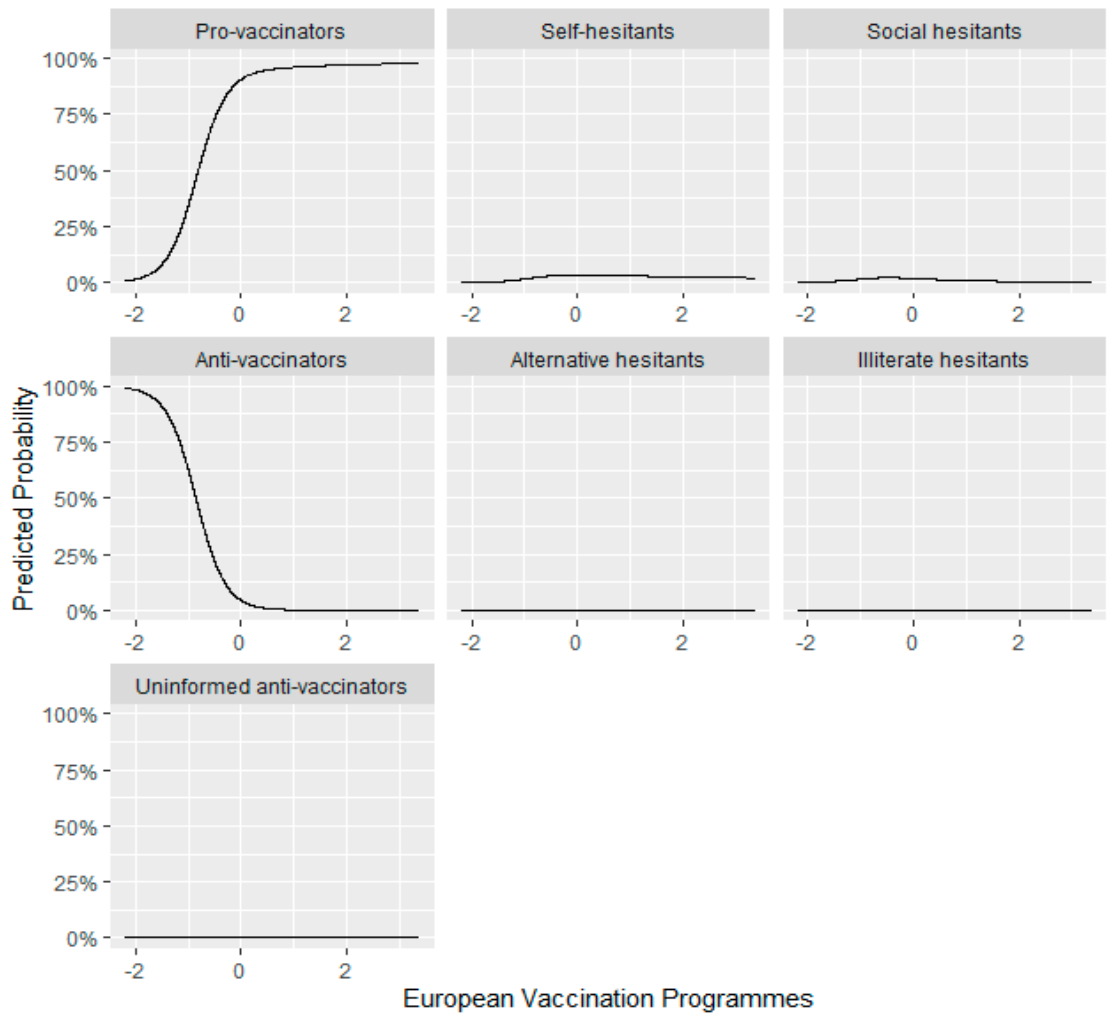

Figure A9. Marginal Effects Multinomial Logistic Regression. European Vaccination Programs.

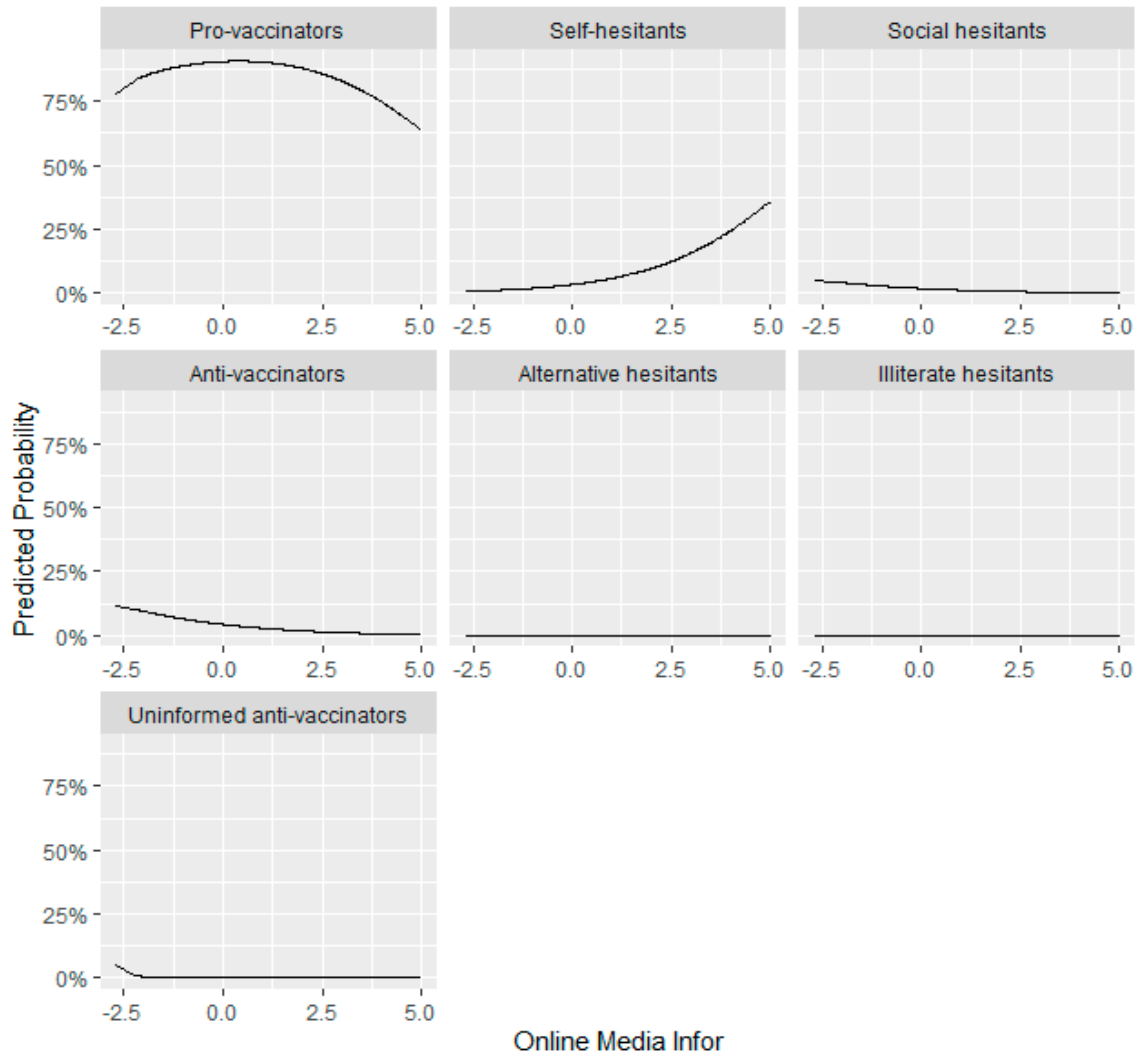

Figure A10. Marginal Effects Multinomial Logistic Regression. Online Media Info. 

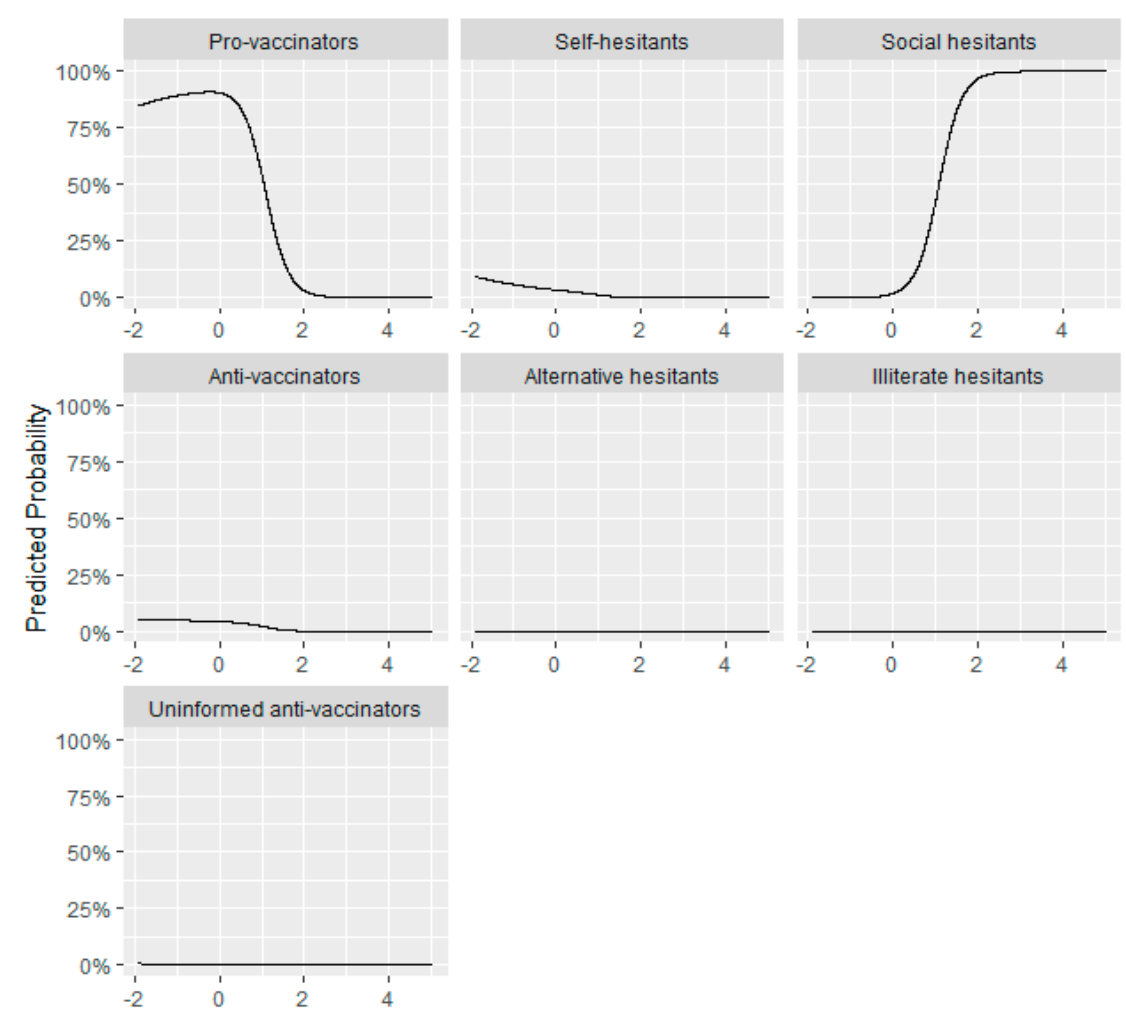

Family \& Friends Info

Figure A11. Marginal Effects Multinomial Logistic Regression. Family and Friends Info.

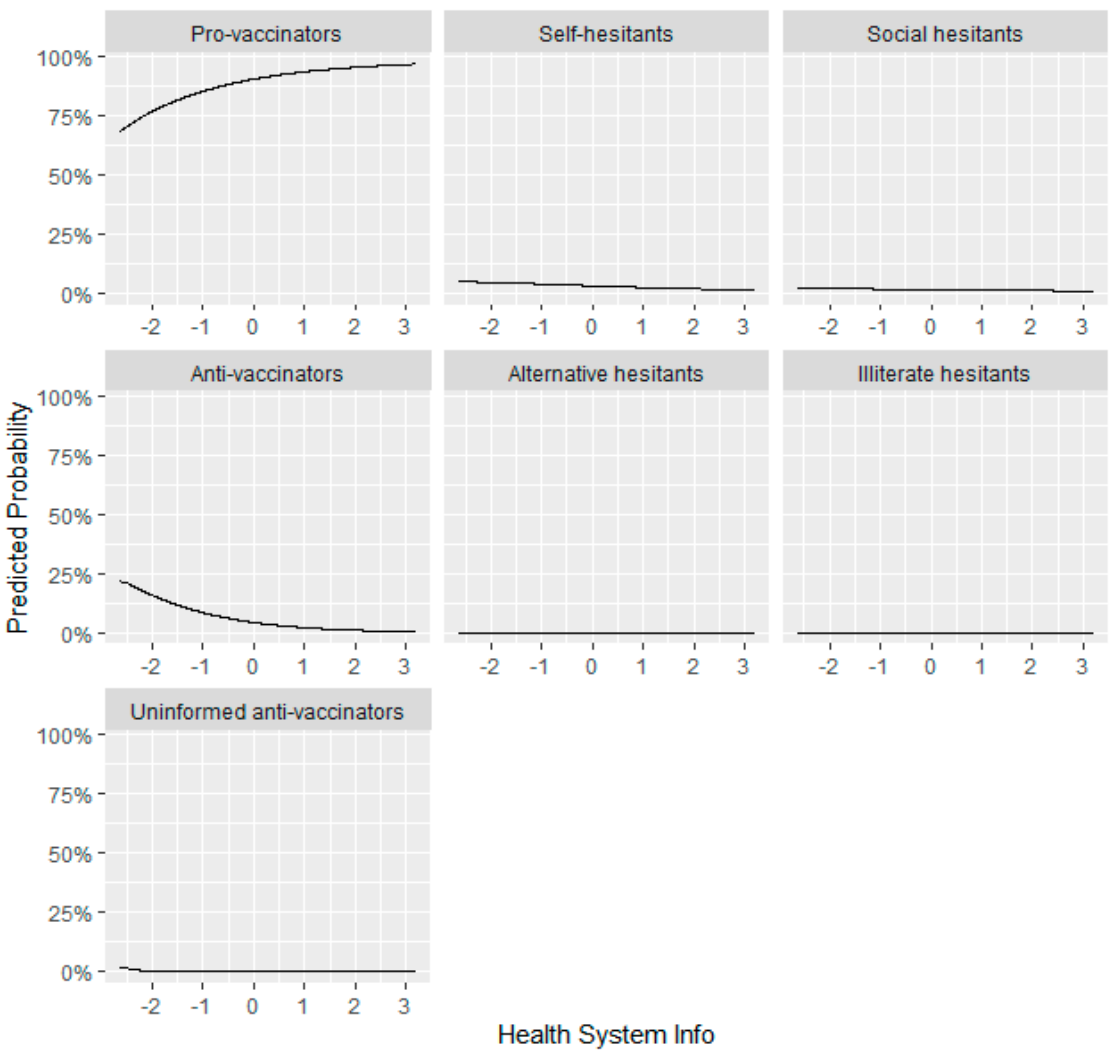

Figure A12. Marginal Effects Multinomial Logistic Regression. Health System Info. 


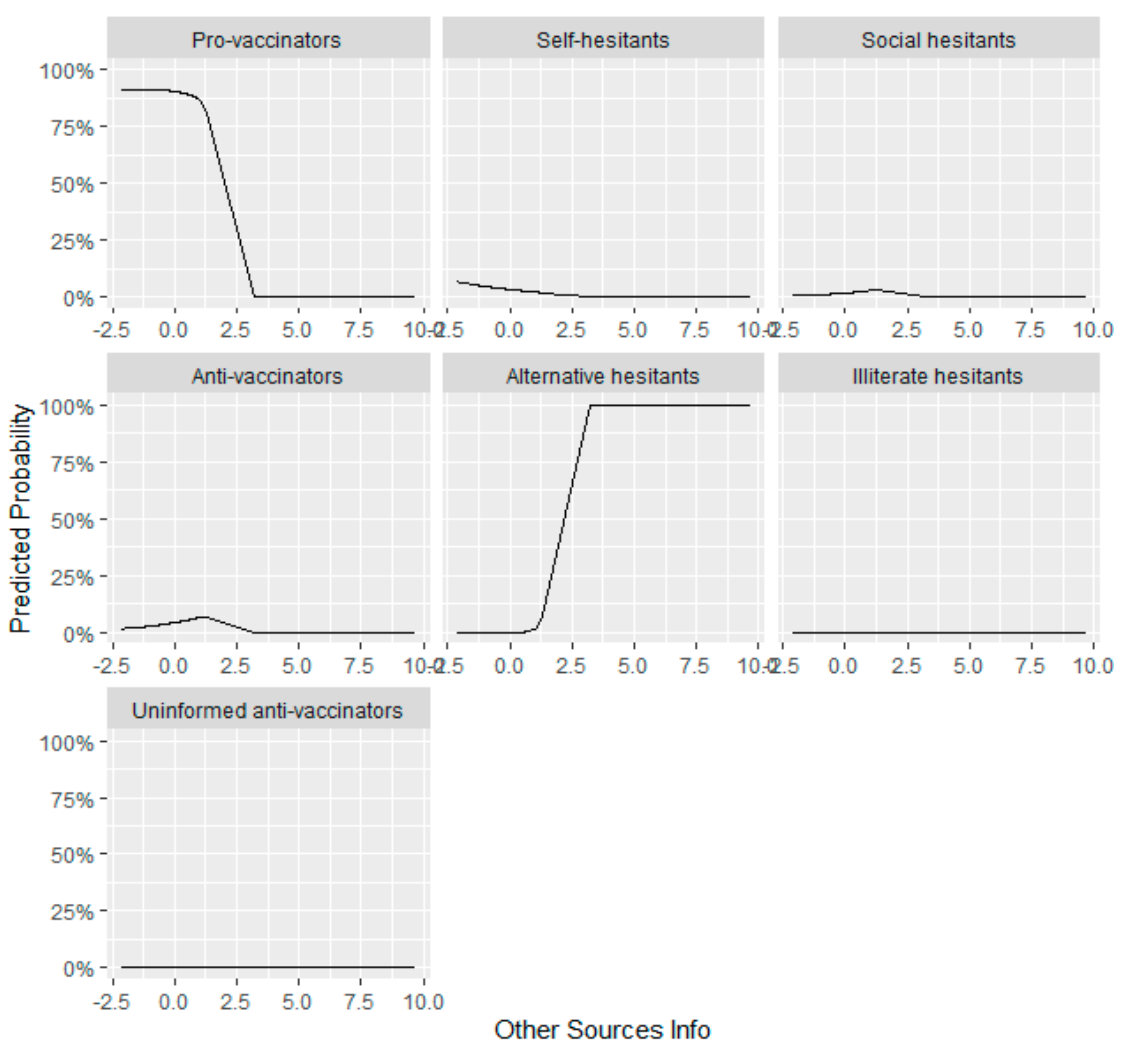

Figure A13. Marginal Effects Multinomial Logistic Regression. Other Sources Info.
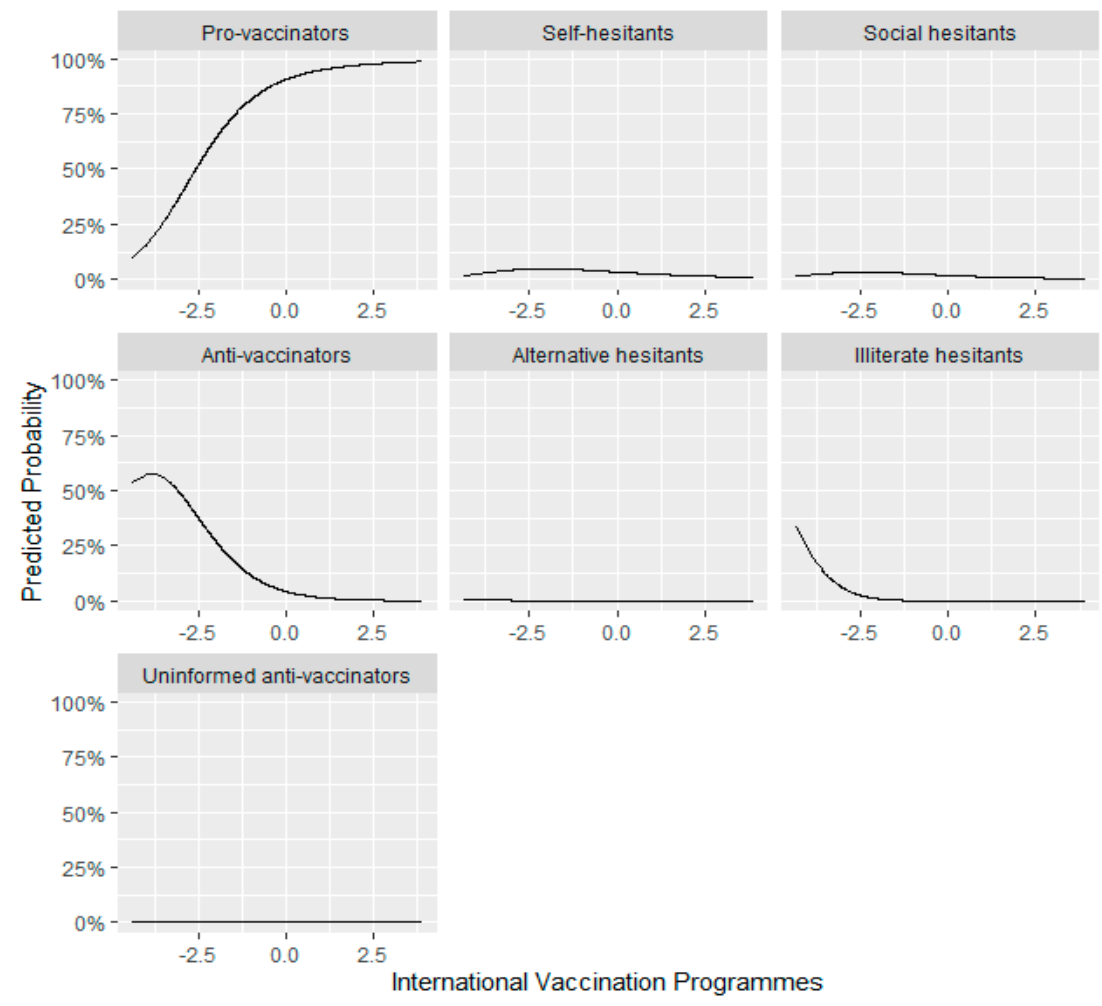

Figure A14. Marginal Effects Multinomial Logistic Regression. International Vaccination Programs. 


\section{References}

1. European Parliament. Resolution of 19 April 2018 on Vaccine Hesitancy and Drop in Vaccination Rates in Europe (2017/2951 RSP). Available online: https://www.europarl.europa.eu/doceo/document/TA-8-2018-0188_EN.pdf (accessed on 20 May 2021).

2. World Health Organization. Ten Threats to Global Health in 2019. Available online: https://www.who.int/emergencies/tenthreats-to-global-health-in-2019 (accessed on 18 December 2020).

3. Williams, G. The Original Antivaxxers. Available online: https://www.economist.com/1843/2019/08/30/the-original-antivaxxers (accessed on 30 July 2020).

4. Little, L.C. Crimes of the Cowpox Ring; The Liberator Pub. Co.: London, UK, 1907.

5. Larson, H.; de Figueiredo, A.; Karafillakis, E.; Rawal, M. State of Vaccine Confidence in the EU 2018; European Union: Luxembourg, 2018.

6. WHO. WHO-UNICEF Coverage Estimates. Available online: https://apps.who.int/immunization_monitoring/globalsummary/ timeseries/tswucoveragemcv1.html (accessed on 1 April 2021).

7. Funk, S. Critical Immunity Thresholds for Measles Elimination. Available online: https://www.who.int/immunization/sage/ meetings/2017/october/2._target_immunity_levels_FUNK.pdf (accessed on 1 April 2021).

8. Lazarus, J.V.; Ratzan, S.C.; Palayew, A.; Gostin, L.O.; Larson, H.J.; Rabin, K.; Kimball, S.; El-Mohandes, A. A global survey of potential acceptance of a COVID-19 vaccine. Nat. Med. 2020, 27, 225-228. [CrossRef]

9. De Figueiredo, A.; Simas, C.; Karafillakis, E.; Paterson, P.; Larson, H.J. Mapping global trends in vaccine confidence and investigating barriers to vaccine uptake: A large-scale retrospective temporal modelling study. Lancet 2020, 396, 898-908. [CrossRef]

10. The Economist Conspiracy Theories about Covid-19 Vaccines May Prevent Herd Immunity. Econ. 2020. 29 August 2020 Edition. Available online: https:/ / www.economist.com/graphic-detail/2020/08/29/conspiracy-theories-about-covid-19-vaccines-mayprevent-herd-immunity (accessed on 1 March 2021).

11. The Council of the European Union Council Recommendation of 7 December 2018 on Strenthened Cooperation against VaccinePreventable Diseases 2018/C 466/0. Available online: https:/ / eur-lex.europa.eu/legal-content/EN/TXT/PDF/?uri=CELEX: 32018H1228(01)\&from $=\mathrm{ES}$ (accessed on 15 May 2021).

12. Dubé, E.; Leask, J.; Wolff, B.; Hickler, B.; Balaban, V.; Hosein, E.; Habersaat, K. The WHO Tailoring Immunization Programmes (TIP) approach: Review of implementation to date. Vaccine 2018, 36, 1509-1515. [CrossRef]

13. French, J.; Deshpande, S.; Evans, W.; Obregon, R. Key guidelines in developing a pre-emptive COVID-19 vaccination uptake promotion strategy. Int. J. Environ. Res. Public Health 2020, 17, 5893. [CrossRef]

14. Fournet, N.; Mollema, L.; Ruijs, W.L.; Harmsen, I.A.; Keck, F.; Durand, J.Y.; Cunha, M.P.; Wamsiedel, M.; Reis, R.; French, J.; et al. Under-vaccinated groups in Europe and their beliefs, attitudes and reasons for non-vaccination; Two systematic reviews. BMC Public Health 2018, 18, 196. [CrossRef]

15. Aurifeille, J.-M.; Quester, P.G.; Lockshin, L.; Spawton, T. Global vs international involvement-based segmentation. A crossnational exploratory study. Int. Mark. Rev. 2002, 19, 369-386. [CrossRef]

16. European Centre for Disease Prevention and Control. Social Marketing Guide for Public Health Programme Managers and Practitioners; ECDC: Stockholm, Sweden, 2014; ISBN 9789291936052.

17. Zou, S.; Cavusgil, S.T. The GMS: A broad conceptualization of global marketing strategy and its effect on firm performance. J. Mark. 2002, 66, 40-56. [CrossRef]

18. WHO. Tailoring Immunization Programmes (TIP) An Introductory Overview; WHO: Geneva, Switzerland, 2018.

19. ECOM Effective Communication in Outbreak Management (ECOM). Available online: http:/ / ecomeu.info/ (accessed on 15 May 2021).

20. TeellMe. Transparent Communication in Epidemics: Learning Lessons from Experience, Delivering Effective Messages, Providing Evidence. Available online: https:/ / www.tellmeproject.eu/ (accessed on 15 May 2021).

21. UNICEF. Human Centered Design 4 Health. Available online: https://www.hcd4health.org/resources (accessed on 15 May 2021).

22. Hallsworth, M.; Snijders, V.; Burd, H.; Prestt, J.; Judah, G.; Huf, S.; Halpern, D. Applying Behavioural Insights WISH Forum 2016; The World Innovation Summit for Health: London, UK, 2016.

23. Jain, S.C. Standardization of International Marketing Strategy: Some Research Hypotheses. J. Mark. 1989, 53, 70. [CrossRef]

24. Schilke, O.; Reimann, M.; Thomas, J.S. Standardization Matter to Firm Performance? J. Int. Mark. 2009, 17, 24-46. [CrossRef]

25. Tan, Q.; Sousa, C.M.P. International Marketing Standardization: A Meta-Analytic Estimation of Its Antecedents and Consequences. Manag. Int. Rev. 2013, 53, 711-739. [CrossRef]

26. Mikulic, M. Global Pharmaceutical Industry-Statistics \& Facts. Available online: https://www.statista.com/topics/1764/globalpharmaceutical-industry/\#dossierSummary_chapter5 (accessed on 15 May 2021).

27. Kennedy, J. Populist politics and vaccine hesitancy in Western Europe: An analysis of national-level data. Eur. J. Public Health 2019, 29, 512-516. [CrossRef]

28. Larson, H.J. The biggest pandemic risk? Viral misinformation. Nature 2018, 562, 309. [CrossRef] [PubMed]

29. Bolton, R.N.; Myers, M.B. Price-Based Global Market Segmentation for Business. J. Mark. 2003, 67, 108-128. [CrossRef]

30. European Commission. Eurobarometer 91.2, March 2019; Gesis Data Archive: ZA7592, Data file Version 1.0.0; Kantar Public: London, UK, 2019. 
31. European Communities. Eurobarometer 63.4. Basic Bilingual Questionnaire TNS Opinion E Social; European Communities: Luxembourg, 2005.

32. Fox, J. Polycor: Polychoric and Polyserial Correlations. R Package Version 0.7-10. Available online: https://CRAN.R-project.org/ package=polycor (accessed on 5 June 2021).

33. Savalei, V. What to do about zero frequency cells when estimating polychoric correlations. Struct. Equ. Model. 2011, 18, 253-273. [CrossRef]

34. Horn, J. A rationale and test for the number of factors in factor analysis. Psychometrika 1965, 30, 179-185. [CrossRef]

35. Osborne, J.W. Best Practices in Exploratory Factor Analysis; CreateSpace Independent Publishing: Scotts Valley, CA, USA, 2014; ISBN 978-1500594343.

36. Tabachnick, B.G.; Fidell, L.S. Using Multivariate Statistics; Pearson: Boston, MA, USA, 2019; ISBN 9780134790541.

37. Yong, A.G.; Pearce, S. A Beginner's Guide to Factor Analysis: Focusing on Exploratory Factor Analysis. Tutor. Quant. Methods Psychol. 2013, 9, 79-94. [CrossRef]

38. Hair, J.F.; Black, W.C.; Babin, B.J.; Anderson, R.E. Multivariate Data Analysis, 7th ed.; Pearson Education Limited: Essex, UK, 2014.

39. Brock, G.; Pihur, V.; Datta, S.; Datta, S. ClValid: An R package for cluster validation. J. Stat. Softw. 2008, 25, 1-22. [CrossRef]

40. Stan Development Team Stan Modeling Language Users Guide and Reference Manual, VERSION 2.26. Available online: https:/ / mc-stan.org (accessed on 5 May 2021).

41. SAS Computing Marginal Effects for Discrete Dependent Variable Models. Available online: https://support.sas.com/rnd/app/ ets/examples/margeff/index.html (accessed on 15 March 2021).

42. European Commission. Special Eurobarometer 488 Report Europeans ' Attitudes towards Vaccination March 2019; European Commission: Brussels, Belgium, 2019.

43. Meyer, D.; Zeileis, A.; Hornik, K. The strucplot framework: Visualizing multi-way contingency tables with VCD. J. Stat. Softw. 2006, 17, 1-48. [CrossRef]

44. Friendly, M. Visualizing Categorical Data. Technometrics 2001, 43, 498-499.

45. Dubé, Ė.; Ward, J.K.; Verger, P.; Macdonald, N.E. Vaccine Hesitancy, Acceptance, and Anti-Vaccination: Trends and Future Prospects for Public Health. Annu. Rev. Public Health 2021, 42, 175-191. [CrossRef]

46. World Health Organization Vaccine Market. Available online: https://www.who.int/immunization/programmes_systems/ procurement/market/individual_vaccine/en/ (accessed on 4 May 2021).

47. Opel, D.J.; Diekema, D.S.; Lee, N.R.; Marcuse, E.K. Social marketing as a strategy to increase immunization rates. Arch. Pediatr. Adolesc. Med. 2009, 163, 432-437. [CrossRef]

48. Nowak, G.J.; Gellin, B.G.; MacDonald, N.E.; Butler, R.; Eskola, J.; Liang, X.; Chaudhuri, M.; Dube, E.; Gellin, B.; Goldstein, S.; et al. Addressing vaccine hesitancy: The potential value of commercial and social marketing principles and practices. Vaccine 2015, 33, 4204-4211. [CrossRef]

49. Washington State Department of Health. Social Marketing Recommendations for COVID-19 Vaccine; Washington State Department of Health: Seattle, WA, USA, 2020.

50. Ahmed, I. Dismantling the anti-vaxx industry. Nat. Med. 2021, 27, 366. [CrossRef] [PubMed]

51. Killian, M.; Detoc, M.; Berthelot, P.; Charles, R.; Gagneux-Brunon, A.; Lucht, F.; Pulcini, C.; Barbois, S.; Botelho-Nevers, E. Vaccine hesitancy among general practitioners: Evaluation and comparison of their immunisation practice for themselves, their patients and their children. Eur. J. Clin. Microbiol. Infect. Dis. 2016, 35, 1837-1843. [CrossRef] [PubMed]

52. Wilson, R.J.I.; Vergélys, C.; Ward, J.; Peretti-Watel, P.; Verger, P. Vaccine hesitancy among general practitioners in Southern France and their reluctant trust in the health authorities. Int. J. Qual. Stud. Health Well-Being 2020, 15, 1757336. [CrossRef]

53. Schmid, P.; Rauber, D.; Betsch, C.; Lidolt, G.; Denker, M.L. Barriers of Influenza Vaccination Intention and Behavior-A Systematic Review of Influenza Vaccine Hesitancy, 2005-2016; World Health Organization: Geneva, Switzerland, 2017 ; Volume 12.

54. Paterson, P.; Meurice, F.; Stanberry, L.R.; Glismann, S.; Rosenthal, S.L.; Larson, H.J. Vaccine hesitancy and healthcare providers. Vaccine 2016, 34, 6700-6706. [CrossRef]

55. Prematunge, C.; Corace, K.; McCarthy, A.; Nair, R.C.; Pugsley, R.; Garber, G. Factors influencing pandemic influenza vaccination of healthcare workers-A systematic review. Vaccine 2012, 30, 4733-4743. [CrossRef] [PubMed]

56. Bahri, P.; Rägo, L. CIOMS Guide To Vaccine Safety Communication-Executive summary. Vaccine 2019, 37, 401-408. [CrossRef] [PubMed]

57. Goldstein, S.; MacDonald, N.E.; Guirguis, S.; Eskola, J.; Liang, X.; Chaudhuri, M.; Dube, E.; Gellin, B.; Larson, H.; Manzo, M.L.; et al. Health communication and vaccine hesitancy. Vaccine 2015, 33, 4212-4214. [CrossRef]

58. Siegrist, M.; Zingg, A. The role of public trust during pandemics: Implications for crisis communication. Eur. Psychol. 2014, 19, 23-32. [CrossRef]

59. Shore, D.A. Communicating in Times of Uncertainty: The Need for Trust. J. Health Commun. 2003, 8, 13-14. [CrossRef] [PubMed]

60. European Commission. Communication from the Commission to the European Parliament, the Council, the European Economic and Social Committee and the Committee of the Regions Strengthened Cooperation against Vaccine Preventable Diseases com/2018/245 Final; Office for Official Publications of the European Communities: Luxembourg, 2018. 